\title{
La lucha por la autonomía a través de la titulación colectiva del territorio
}

Ta región del Alto Naya es un territorio geográfico de más de Ltrescientas mil hectáreas, que se extiende desde la formación rocosa de los Farallones de Cali al oriente hasta la costa Pacífica en el occidente, bañada por la hoya del río Naya. Como universo microsocial, lo que acontece en el Alto Naya ofrece los elementos para comprender en alto grado algunos factores que han caracterizado el conflicto político, social y armado que ha experimentado Colombia por décadas; para las comunidades que habitan esta exuberante y agreste región, la perpetración de la masacre en abril de 2001 por el bloque Calima de las Autodefensas Unidas de Colombia tan solo es la punta del iceberg en un conflicto que históricamente ha tenido como foco principal la lucha por la posesión, uso y titulación de la tierra. Para contextualizar el argumento, es clave referir tres realidades que caracterizan la dinámica regional:

1. Se trata de una estratégica zona geográfica por ser un corredor natural que conecta la cordillera Occidental con la costa Pacífica. De ahí que sea un territorio que se busque dominar en términos militares — la presencia paramilitar desde comienzos 
del año 2000 buscó, ante todo, disputarle tanto al ELN como a las Farc-EP el control de la región-. De igual forma, es un territorio propicio para el cultivo, transporte y comercio de hoja de coca, lo que entraña disputas por su dominio.

2. En la región cohabitan tres grupos claramente definidos —aborígenes, afrodescendientes y campesinos- sin que se tenga una cifra cierta del total de la población. Los últimos datos corresponden a un encuentro interétnico celebrado en el año $2003^{19}$, que documenta una población de 22833 personas discriminadas de la siguiente forma: 3505 aborígenes de los pueblos nasa $(14 \%)$ y eperara siapidara (1\%); 17000 afrodescendientes $(78 \%$ ) asentados en las zonas del Medio y Bajo Naya; 1118 campesinos (5\%); 1200 personas en condición de desplazamiento (5\%) (Caicedo, L. y otros, 2006, p. 14). Tampoco se tiene precisión de la población considerada como "flotante", conformada por campesinos que se integran a los ciclos de producción en el cultivo y recolección de hoja de coca. Exceptuando las comunidades del resguardo indígena de Joaquincito y del Consejo Comunitario de Comunidades Negras del Río Naya ${ }^{20}$, el grueso de las comunidades no cuenta con títulos de propiedad.

19 En la actualidad las comunidades coordinan con la Dirección de Etnias del Ministerio del Interior y el Departamento Administrativo Nacional de Estadística (Dane) para que adelante un censo poblacional. La expectativa de los pobladores es que el censo se adelante pronto, dada la desmovilización de las Farc-EP como grupo insurgente.

20 Es importante acotar que la figura del resguardo como institución sociopolítica de origen colonial sufre un cambio trascendente con la Constitución Política de 1991 en cuanto comienza a considerarse como entidad territorial junto con los departamentos, municipios y distritos (artículo 286). Esta condición implica que gozan de autonomía administrativa en un territorio de titulación colectiva y que participan de las rentas nacionales. Por su parte, el Consejo Comunitario de Comunidades Negras es una figura sociopolítica con personería jurídica que emerge del artículo 5 de la Ley 70 de 1993, posibilitando que las comunidades afrodescendientes tengan título de propiedad colectiva sobre la tierra que han habitado históricamente. Esta apertura es producto 
3. En términos administrativos, la región está dividida entre la jurisdicción de los departamentos del Valle del Cauca (municipio de Buenaventura) y el Cauca (municipios de Buenos Aires y López de Micay). Esta fragmentación implica en la práctica de las comunidades la dispersión obligada de las demandas (Caicedo, L. y otros, 2006, p. 13). En el Valle del Cauca se ubican seis veredas: La Playa, Pico de Loro, Las Minas, Miravalle, El Edén y Santa Helena; y en el Cauca, se ubican diez veredas: El Placer, Pitalito, La Paz, Río Azul, La Vega, Las Brisas, El Sinaí, Lomalinda, El Playón y Río Mina.

En ese contexto, la lucha por el derecho al territorio - que en el departamento del Cauca se remonta a los años setenta con la aparición del movimiento indígena (Gros, 1991; Findji, 1992; Avirama y Márquez, 1995; Jimeno, 1996; Tattay, 2013)—, es la consigna más importante para las comunidades del Alto Naya antes y después de la perpetración de la masacre. De hecho, las disrupciones y los impactos provocados por la presencia del bloque Calima en la zona, incluyendo la acción paramilitar de abril de 2001, es el eje alrededor del cual se enmarca la principal reivindicación o reparación que podrían obtener las comunidades: la titulación colectiva de la tierra.

En consecuencia, el presente capítulo reflexiona sobre los procesos de agencia adelantados por las comunidades del Alto Naya precisamente para obtener los títulos de propiedad colectiva sobre unos territorios que han sido habitados desde hace más de sesenta años. El recorrido, entonces, parte de los recuerdos sobre los primeros pobladores que llegaron a la región tumbando selva y huyendo de la violencia partidista de los años cincuenta, desatada tras la muerte del caudillo liberal Jorge Eliécer Gaitán; pasa por los años ochenta cuando se asientan en

del reconocimiento constitucional de Colombia como un Estado pluriétnico, permitiendo, incluso, que representantes de los pueblos originarios y afrodescendientes tengan participación en el parlamento. Sobre la Constitución de 1991 y los pueblos indígenas véase Correa (1992, 1993), Gros (1993), Rappaport (1996) y Van Cott (2000). 
la región las Farc-EP y el ELN, en momentos en que también comienza el auge de los cultivos de coca; llega a la actividad comunitaria de los últimos años, cuya meta ha sido lograr consensos entre los tres grupos poblaciones involucrados respecto a la figura social, política y jurídica sobre la cual eventualmente el Estado pueda otorgar títulos de propiedad colectiva.

El recorrido, el análisis y la reflexión son producto de un trabajo de campo etnográfico que se adelantó con las comunidades en varios momentos entre 2010 y 2013. Considero pertinente enfatizar que el trabajo se realizó en distintos momentos porque las condiciones de seguridad literalmente impidieron el ideal de tener una permanencia de largo aliento, limitando el ejercicio a encuentros cortos (entre tres y cuatro días) que en su mayoría se dieron en la realización de algún encuentro local, regional o nacional, así como en el acompañamiento a las personas que asistieron a las audiencias de Justicia y Paz.

La complejidad de realizar trabajos de investigación en contextos donde aún predomina lo que las poblaciones en su cotidianeidad reconocen como escenarios de guerra, invita a crear estrategias que traten de garantizar la comunicación a través de la distancia física, así como la "presencia" desde lugares que no se agotan con el encuentro cara a cara. Por lo mismo, quiero destacar la importancia de emplear los dispositivos tecnológicos que son un recurso valioso para mantener una comunicación permanente, que complementa el trabajo etnográfico. Ahora bien, el uso de las tecnologías como recursos también trae consigo situaciones complejas que interpelaron en más de una oportunidad mi condición como investigador. Por ejemplo, aún persiste la fuerte sospecha respecto a que buena parte de las comunicaciones sostenidas a través de teléfono móvil fueron interceptadas, teniendo en cuenta que los líderes del Naya son objetivos militares de varios actores. De igual forma, en algunas ocasiones fui contactado por los líderes para colaborar en el trámite de una denuncia ante organismos del Estado, agencias de derechos humanos y organizaciones nacionales indígenas. Lo cierto es que mantener el rol aséptico de investigador que trata de fijar distancias no es posible cuando se comprende que en el ejercicio hay unas dimensiones éticas y políticas que determinan el trabajo. 


\section{La fundación del Naya}

Para reconstruir la historia de la fundación de la región del Naya se apeló a los recuerdos de los ancianos, cuyos abuelos llegaron a la región a mediados del siglo pasado huyendo de la violencia partidista entre liberales y conservadores que se desató con el asesinato de Jorge Eliécer Gaitán, lo que hace aparecer en las narraciones unas violencias yuxtapuestas que, además de marcar una continuidad, expresan una historia de desplazamiento constante y sistemático ${ }^{21}$ :

Mi abuelo, Luciano Guetio, llegó a mediados de 1948 al municipio de Timba (Valle del Cauca) luego de que le mataran a su familia, a su papá y a su mamá; decidió huir con mi abuelita, ambos eran muy jóvenes. Vivieron en Timba como dos años, hasta que un vecino les comentó que detrás de la cordillera (Occidental) había unas tierras bien buenas, pero que estaban bastante lejos. El abuelo decidió probar suerte porque estaba cansado de vivir de posada y de trabajar para otros, y que lo mejor era buscar tierras propias. Él me contó que se gastó tres meses trochando [tumbando selva] para llegar a lo que hoy se conoce como la región del Alto Naya. (Elvira Cundé, notas de campo, marzo de 2011)

La otra figura que evocan los pobladores como fundador de la región es Luis Cunda, quien entró por el camino del municipio de Jamundí, Valle del Cauca. Sostiene Irma Guasaquillo:

El fundador llegó a la región huyendo de la violencia, más o menos, para el año 1950. Él también abrió la trocha (camino de herradura) y llegó a la orilla del río Naya y le gustó el lugar. Luego llegaron otras familias que lo seguimos a él: la familia Ramos, con don Luis Ramos, la familia Mestizo (Tattay, 2011).

21 Esto corresponde a la zona del Alto Naya. En la parte del Bajo y Medio Naya los primeros asentamientos datan del siglo XVII, cuando se establecen enclaves mineros que emplean mano de obra de población negra esclavizada. Con la abolición de la esclavitud en 1851, la población negra se distribuye por toda la región y se asienta en zonas ribereñas en pequeños poblados (García y Jaramillo, 2008, p. 13). 
Como buena parte de los relatos fundacionales (Bajtín, 1989, p. 451; Ricœur, 2006, p. 784), los testimonios se caracterizan por una marcada carga de acciones heroicas-épicas en las que subyacen los sentidos construidos a lo largo de los años, a partir de los cuales esas familias desarraigadas reconfiguran sus identidades (Hall, 1997, p. 4; Anderson, 1993, p. 23) en historias que, sin duda alguna, también expresan la dignidad que guardan unas comunidades en permanente resistencia (Gnecco y Zambrano, 2000, p. 14):

Cuando el abuelo estaba abriendo trocha [camino] se guiaba montándose en los árboles para tratar de ver los ríos, así se daba cuenta para dónde iban y dónde desembocaban. Plantaba una mata de plátano en un lugar y se devolvía, marcando los sitios, hacia Timba. Recuperaba fuerza y cuando tenía todos los implementos para regresarse, volvía a seguir trochando. El primer río que cruzó, con cuerdas, fue uno que hoy se conoce como El Ceral. Luego siguió trochando como un mes y medio para llegar a un lugar conocido como Las Brisas [una vereda]. Allí hizo un cambuche [refugio], sembró plátano, caña y papa. Vivió como un año hasta que salió a buscar a mi abuelita para que los dos se fueran a vivir... Detrás de mi abuela se vino un tío de ella, Julián, que también fue desaparecido por los paramilitares. En Las Brisas nació mi mamá, porque mi abuela ya venía embarazada. Ellos trabajaron un par de años más en ese lugar hasta que decidieron cruzar la cordillera para llegar a un sitio que se conoce como Río Mina. Allí se ubicaron, en un terreno de más o menos ciento cuarenta hectáreas, y comienzan a trabajar para la llegada de otras familias. Estando en Río Mina conoce [la vereda] La Playa y se encuentra con otras familias que también fueron fundadores pero que entraron por la parte del Valle del Cauca. Todos comienzan a trabajar por una causa común, porque todos llegaron buscando nuevos caminos, nuevas esperanzas. Todos fueron despojados de algo y el Naya fue la oportunidad para comenzar de nuevo. En el Cauca las familias fundadoras fueron los Quiguanas, Ramos y Escué; en el Valle las familias fundadoras fueron los Valencia, Izú y Guasaquilla. (Elvira Cundé, notas de campo, septiembre de 2013) 
El relato de Elvira va más allá: ella sabe que esa historia fundacional es en el fondo el principal argumento de lo que las familias del Alto Naya, cincuenta años después, tuvieron que volver a vivir cuando los paramilitares del bloque Calima los obligaron a desplazarse, para luego volver a retornar para "comenzar de nuevo". Relatar cómo fundaron los abuelos cada una de las veredas es un acto contra el olvido, una forma de recuperar el tiempo, y también es una manera de avanzar en él (Portelli, 1993, p. 162), pues el acto de recordar permite recomponer las identidades que quedaron fracturadas con la masacre. Y así como en los años cincuenta los abuelos fundaron El Naya desafiando la agreste naturaleza de la cordillera para tener "un terreno propio", en la actualidad hay que seguir luchando para que ese derecho se materialice en un título sobre el territorio ${ }^{22}$.

Ahora bien, la mayoría de personas con las que conversé para que me contaran la historia de la región del Naya destacaron en sus relatos dos aspectos que son una especie de leitmotiv: por un lado, territorio, familia y naturaleza como ejes de la vida social y comunitaria; por otro, la emergencia del cultivo de la coca como la caja de Pandora que abre los males a la región.

Como lo recuerda Alessandro Portelli (1993), "los relatos que tratan de reconstruir el pasado procuran seguir una secuencia lineal que permite al narrador organizar una historia que jamás será contada del mismo modo" (p. 167), descomponiendo el tiempo tanto en forma horizontal, para ubicar bloques homogéneos que marcan un "antes" y un "después", como en forma vertical, vinculados a la actualidad de unos recuerdos que se organizan en modalidades de tipo ético-político, colectivo o personal. En consecuencia, fechar un acontecimiento, por ejemplo, implica ubicarlo en un horizonte temporal, y especialmente

22 De ahí que los relatos sobre los desplazamientos ocurridos en 2000 y 2001, ambos perpetrados por el bloque Calima, destaquen la figura de Alexander Quintero como la persona que lideró el proceso de retorno de las familias y las demandas de reivindicación en torno a la titulación de la tierra. Quintero fue un líder comunal, asesinado en diciembre del año 2010, lo cual vuelve más heroica su figura. 
implica escoger una modalidad que lo enmarca, acotando que un mismo acontecimiento puede formar parte de las tres modalidades.

Respecto al primer aspecto, que la tierra, la familia y la naturaleza sean los ejes sustanciales de la vida social de las comunidades del Alto Naya, indica la fuerte injerencia de las concepciones del pueblo nasa en las comunidades, indistintamente de si estas son afrodescendientes o campesinas. De acuerdo con la cosmogonía nasa ${ }^{23}$, la tierra representa la vida y la madre, lugar donde se nace, se recrea, se convive y se produce la existencia; la familia es la puntada de un tejido social que se extiende como "una telaraña que se sobrepone para poder existir y resistir, como pueblos, ante los sistemas de opresión y aniquilamiento a que hemos estado sometidos desde la conquista de los españoles" (Onic, 2003, p. 106); la naturaleza es el complemento de la vida, lo que demanda una relación de equilibrio y reciprocidad con el hombre. Esta concepción, a mi modo de ver, también demuestra la capacidad política que han tenido las comunidades en los años que siguieron a la perpetración de la masacre, para llegar a unos consensos que les permitieran agenciar con las entidades gubernamentales y estatales demandas y reivindicaciones bajo la condición de "pobladores del Naya", lo que indica criterios de unidad.

Sobre el segundo aspecto, en los testimonios hay un encuadramiento de los recuerdos que ubican la llegada del cultivo de la coca como el factor que marca la desestabilización social, política y económica de la región. Las remembranzas permiten situar dos grandes momentos, imbricados, además, en las dinámicas económicas de la región:

23 El pueblo nasakiwe está ubicado al sur de los Andes colombianos, en la región de Tierradentro, entre los departamentos de Cauca y Huila (Arango y Sánchez, 1998). Nasa significa gente y vida, mientras kiwe representa un territorio dividido en tres mundos. Dado que nasakiwe es un término compuesto por dos palabras que se implican mutuamente (nasa es todo lo que existe en el kiwe y en este todo es nasa), la traducción castellana más acertada sería "la gente de su territorio"; el término implica un sentido de pertenencia espacio-cultural y una concepción de mundo que marca un límite entre el adentro y el afuera (Gómez, 2000, p. 23). 
- Para finales de los años setenta llega a la región una variedad de coca conocida entre los pobladores con el nombre de "pajarita". Los testimonios cuentan que la semilla de la hoja fue traída por los propios indígenas, pero que su uso estuvo siempre destinado al mambeo (masticar la hoja de coca). Los pobladores indican que la planta desapareció rápidamente por tres posibles razones: algunos dicen que su extinción fue producto de una enfermedad que mató la planta; otros sostienen que la planta fue erradicada por las fumigaciones con herbicida que se dieron para mediados de los ochenta ${ }^{24} ;$ y otros creen que la planta simplemente fue reemplazada por la semilla de hoja de coca proveniente del Perú. Lo particular de los testimonios es que tampoco dudan en asociar la llegada de los cultivos ilícitos con las migraciones de familias campesinas que se asientan en la región. Al respecto, cuenta Elvira:

Con el auge de la coca llegan los campesinos y empiezan a decirle a los nativos de la región que en vez de criar marranos y gallinas cultiven coca, porque era un cultivo más rentable y que ofrecía más calidad de vida. Lo cierto es que la coca ha traído una economía ilusoria que desestimuló el trabajo en tules (trabajo en el cultivo de la tierra), ha generado descomposición social y amenaza la seguridad alimentaria de la región porque se está deforestando el monte... (Elvira Cundé, notas de campo, noviembre de 2012)

24 Cabe recordar que la política de fumigaciones de cultivos ilícitos se remonta al año 1978, cuando el gobierno de Julio César Turbay Ayala decide asperjar los cultivos de marihuana con el herbicida paraquat en la Sierra Nevada de Santa Marta. La fumigación fue suspendida por el Instituto Nacional de los Recursos Naturales Renovables y del Ambiente (Inderena), autoridad ambiental de la época, al solicitar al Consejo Nacional de Estupefacientes (CNE) adelantar un estudio de impacto ambiental. Tras varios años de suspensión, las fumigaciones con glifosato volvieron para el año 1984, tras la presión ejercida por la administración de Ronald Reagan como estrategia central de la lucha contra las drogas (Vargas, 2002). 
- El otro momento arranca, según los testimonios, en la segunda mitad de la década de los ochenta, cuando el cultivo de la coca, sin distinción de su procedencia, se instala como la principal actividad económica en buena parte de la región. Los pobladores recuerdan que solo en las veredas ubicadas en la entrada del Naya (El Ceral, Pueblo Nuevo, Aures, Cerro Azul, El Palmar y San Antonio) no cultivan la planta por razones religiosas, pues son comunidades evangélicas que, además, cuentan con buenas vías de acceso, cercanas al municipio de Timba (Onic, 2003, p. 107). El punto es que, en un contexto más amplio, la emergencia y la consolidación del cultivo de hoja de coca en el sur del área andina colombiana coincide con el endurecimiento de la política antidrogas de Washington en Perú y Bolivia, lo que obliga a que Colombia — que tradicionalmente se había especializado en el procesamiento de la pasta de coca y en la distribución de la cocaína- se convierta en país productor, lo que afianza la relación entre el capital del narcotráfico y las fuerzas insurgentes (Vargas, 2002, p. 79). A la postre, será esta situación la que justifique que, una década más tarde, se implemente, durante la administración Clinton, una política de lucha contra las drogas que, ante el fin de la Guerra fría ${ }^{25}$, convierte a los grupos insurgentes - como las Farc-EP- en los nuevos “enemigos" de la democracia mundial. El Plan Colombia será, entonces, la nueva cruzada militarista y neocolonial que, sobre la base de la lucha contra las drogas, combatirá en Colombia a las Farc-EP como grupo ahora considerado “terrorista”. En el escenario local, los pobladores lamentan que el cultivo de coca reemplazara los cultivos tradicionales, en especial de yuca, plátano, fríjol, maíz, zapallo, malanga (una variedad de papa)

25 Siguiendo la tesis de Corey Robin (2009) sobre el miedo como idea política, con el fin de la Guerra fría y el triunfo del libre mercado, los intelectuales contemporáneos de Estados Unidos y Europa, que otrora lucharon por cambios radicales en el interior de sus propias sociedades, enfocan su "artillería insurgente” en las “tiranías lejanas”, sean éstas los Balcanes, el Medio Oriente, el mundo musulmán o la Revolución bolivariana (p. 253). 
y café, y la crianza de gallinas, patos y marranos. Rosa Ipía, habitante de la vereda La Paz, recuerda con nostalgia los tiempos en que su familia vivía del cultivo del cacao y de la caza:

Eran tiempos de tranquilidad. Recuerdo cuando mi abuelo y mi papá salían muy de madrugada a pescar y cazar guaguas (roedor grande), tatabros (mamífero mediano de la familia del cerdo), guatines (roedor mediano), pavos, loros y micos. (Rosa Ipía, notas de campo, septiembre de 2013)

La injerencia del cultivo de coca en la región del Naya también tuvo un efecto en la estructura política y organizativa de las comunidades. A pesar de la cosmogonía del pueblo nasa en el ámbito social y cultural - reflejado en los principios solidarios de la minga ${ }^{26}$ y en las relaciones de parentesco, compadrazgo y vecindad-es paradójico que los espacios organizativos más representativos no fueran el cabildo y el resguardo. Nuevamente los recuerdos de líderes como Elvira Cundé ofrecen luces al respecto:

En los años setenta, hizo presencia una iglesia evangélica, la Unión Misionera, quien lideró a través del culto muchos de los procesos comunitarios en un trabajo que, recuerdo, iba puerta a puerta y promovía el encuentro entre vecinos. Luego aparecieron las juntas de acción comunal, que en esos años [comienzo de los años ochenta] tenían un tinte politiquero, porque eran el fortín de los políticos de la época, que nos ayudaban con los famosos auxilios parlamentarios, sobre todo para arreglar los caminos, construir uno que otro puente y sentar las bases de las escuelas. Pero las juntas han sido muy importantes, porque nos ha permitido organizarnos e impulsar demandas. En la actualidad la región cuenta con catorce juntas de acción comunal, diez en el Cauca y las otras en el Valle. (Notas de campo, septiembre de 2013)

26 Antigua tradición aborigen de trabajo comunitario o colectivo con un objetivo social. Para los abuelos indígenas del Cauca el trabajo compartido, el trabajo en minga, es para el bien común. 
Las discusiones sobre la importancia de que las comunidades se organizaran en torno a la figura del cabildo se registran en la década de los noventa y se materializan en 1994, cuando se conforma el Cabildo Indígena del Naya, con el apoyo del partido político Movimiento Indígena de Colombia (Aico). En la actualidad, existen cuatro cabildos más, dos en el Cauca y dos en el Valle, creados después de la masacre: Cabildo Comunidad Sinaí Nasawala y Cabildo Comunidad El Playón Nasawala en el Cauca; Cabildo Indígena del Alto Naya Paez de La Playa y Cabildo Aguas Limpias de Pico de Loro en el Valle. En síntesis, en la región del Naya coexisten organizativamente tres figuras: los cabildos indígenas, el Consejo Comunitario del Río Naya, de la población afrodescendiente, y las juntas de acción comunal, que aglutina, en la mayoría de los casos a indígenas, negros y campesinos. Pero ¿por qué es tan importante en la actualidad la figura del cabildo para las comunidades del Alto Naya, incluyendo aquellas que no tienen un origen indígena? ¿Cuál es el rol de esta figura de origen colonial en relación con la reivindicación del derecho al territorio?

Como lo recuerda Pablo Tattay (2013), una estrategia eficaz de los pueblos indígenas del Cauca, paradigmática para las comunidades del Naya en los procesos que adelantan, ha sido la reapropiación de instituciones y leyes ajenas a sus tradiciones y costumbres. Siendo el cabildo y el resguardo figuras de origen colonial que se impusieron a los aborígenes. Destaca Tattay que la originalidad y la eficacia del movimiento caucano sigue estando en capacidad de reapropiarse de las instituciones y de los escenarios para ponerlos al servicio de las causas y demandas colectivas (2013, p. 55). Así ocurrió con la Ley 89 (1890) como norma expedida bajo la constitución de 1886 para regular la relación con las poblaciones aborígenes. Más allá de su tono excluyente, racista y discriminatorio, expresado en la consideración de los indígenas como bárbaros que deben ser civilizados a través de las misiones religiosas, la norma, que aún sigue vigente, establece la protección de los resguardos en la medida en que define que son territorios imprescriptibles, inembargables e indisolubles, y reconoce a los cabildos como legítimas y auténticas autoridades indígenas con amplias facultades. En consecuencia, el movimiento indígena del Cauca comprende que la norma es una herramienta valiosa para recuperar 
el territorio, y sobre todo para validar y legitimar las reivindicaciones frente al Estado. Por ejemplo, en los casos en los que los territorios fueron puestos a disposición de mercado, buscando anular cualquier tipo de compraventa (Tattay, 2013, pp. 57-59).

Las comunidades indígenas saben que estas clasificaciones y denominaciones de salvajes, semisalvajes o civilizados, y de maduros e inmaduros sociológicos los discriminan y niegan su acervo cultural; pero también saben que son armas con las cuales se pueden defender y evitar que se cometan más injusticias y puedan solucionar conflictos a los que se ven abocados. En esa medida son normas que han sido utilizadas con éxito en otras oportunidades. (Gros, 1991)

El cabildo, entonces, se convierte en el eje político y organizativo para la resistencia en la medida en que afianza la idea que históricamente han buscado las comunidades: apostar por el "gobierno propio" (Tattay, 2013, p. 53). En otras palabras, a través del fortalecimiento de los cabildos las comunidades del Naya han cimentado la estrategia para adelantar la tarea de un territorio titulado, pero esa estrategia ha sido la misma que desde los años setenta han seguido los pueblos indígenas del Cauca, aglutinados organizativamente en el Consejo Regional Indígena del Cauca (Cric), para adelantar el que sigue siendo su principal frente de lucha: la recuperación de los territorios y su reconocimiento mediante la figura del resguardo (Tattay, 2013, p. 54). En síntesis: la recuperación de los resguardos es simplemente una condición indispensable para el desarrollo de la autonomía. De igual forma ocurre con el cabildo como eje central del proceso organizativo y político.

\section{La situación territorial en la región del Alto Naya: antes y después de la masacre}

En la historia reciente de Colombia la masacre se convirtió en una expresión de violencia armada con profundas disrupciones en la vida cotidiana. Para ejemplificar el asunto, basta recordar que la dramática cifra de poco más de cinco millones de personas desplazadas en la 
actualidad, indica que el destierro y el despojo de sus territorios tuvo como acto previo una masacre (CNMH, 2014). En consecuencia, la masacre hay que entenderla como un acto político-militar para desalojar y apropiarse de territorios considerados estratégicos en términos políticos y, sobre todo, económicos (Uribe, 1990; Molano, 2002; VásquezZawadzi, 2002). Por esto, es posible que, en los ejercicios de memoria que buscan rastrear los sentidos construidos en torno a ese pasado violento, la masacre sea un evento "privilegiado" en torno al cual se organizan versiones que, parafraseando a Portelli (1996), determinan un antes y un después (pp. 24-25). La masacre perpetrada por el bloque Calima contra las comunidades indígenas, afrodescendientes y campesinas en la región del Alto Naya en abril de 2001 no escapa a esta dinámica, al punto que el acontecimiento es reconocido en el ámbito nacional como la "masacre del Alto Naya”. Pero, como dije párrafos atrás, la perpetración de la masacre es la punta del iceberg en la que se expresan conflictos históricos por el uso y el derecho a la tierra, agudizados en la década de los ochenta, así como las estrategias de resistencia de las comunidades para reivindicar y dignificar esos derechos vulnerados, siendo la masacre de abril de 2001 el evento a partir del cual se reconfiguran las estrategias para demandar del Estado la titulación colectiva de los territorios.

Para comprender mejor los argumentos, conviene bosquejar lo que ha sido el patrón de despojo de tierras y el desplazamiento de poblaciones por control y dominio de aquellas en relación con la confrontación armada. Según las cifras de la Tercera Encuesta Nacional de Verificación de la Comisión de Seguimiento a la Política Pública sobre Desplazamiento Forzado (Garay y Vargas, 2011), entre 1980 y 2010 se abandonaron cerca de 6.6 millones de hectáreas, es decir, el $15.4 \%$ de la superficie agropecuaria del país, afectando a cerca del $10 \%$ de la población colombiana. Ese despojo sistemático fue concentrando la propiedad, lo que también indica complejos entramados jurídicos para su legalización, puesto que implica lo que Garay denomina actores 
grises que actúan entre la legalidad y la ilegalidad ${ }^{27}$; en contraste, hay una elevada informalidad jurídica de las comunidades rurales con la tierra, donde un $70 \%$ son simplemente poseedores que no cuentan con un registro o título de propiedad (Garay y Vargas, 2011, pp. 16-17).

Un segundo aspecto está en las características de los hogares (integrados en promedio por cinco miembros) que han sido obligados a abandonar sus tierras. El $45 \%$ de ellos tienen jefatura femenina y de ellos el $70 \%$ son mujeres sin cónyuge. Lo anterior se agrava en la medida en que el $40 \%$ de la población desplazada es menor de 15 años. Las cifras también indican, según Luis Jorge Garay que dirige los estudios, que el $97 \%$ de los hogares está por debajo de la línea de pobreza y un $78 \%$ por debajo de la línea de indigencia.

Un tercer aspecto que ratifica las cifras que arroja la Tercera Encuesta Nacional de Verificación de la Comisión de Seguimiento a la Política Pública sobre Desplazamiento Forzado es que el desplazamiento y el despojo se debieron a la violencia, siendo los grupos paramilitares los principales responsables, seguido por las Farc-EP, el ELN y algunos grupos armados ilegales no identificados. Este hecho demuestra que el desplazamiento y el despojo responden a una estrategia sistemática, puesto que el $40 \%$ de los desplazamientos ha sido masivo (más de diez hogares simultáneamente) y el $28 \%$ ha sido grupal (entre dos y diez hogares simultáneamente).

Un cuarto aspecto es que en el $82 \%$ de los casos se registraron saqueos sobre bienes materiales que usualmente no son cuantificados: herramientas, maquinarias, animales y cultivos. Las pérdidas inmateriales son prácticamente invisibles.

Finalmente, las cifras indican que el $30 \%$ de los hogares encuestados no conoce la suerte corrida con la propiedad despojada, lo cual

27 Las modalidades de despojo incluyen procesos de intimidación que obligan a que la tierra sea vendida a precios irrisorios o que se obligue al campesino a transferirla a los perpetradores o a sus testaferros. De igual forma, es frecuente que los terrenos abandonados por largos periodos hayan sido tomados en posesión por terceros de buena o mala fe (Garay y Vargas, 2011, p. 20). Las investigaciones judiciales han demostrado que el proceso cuenta con la complicidad de los notarios (escribanos). 
es grave en la medida en que, a pesar de la relación informal con la tierra, casi la totalidad de las familias desplazadas y despojadas ya tenía una posesión de más de 20 años, lo que garantizaba una relación formal de facto con la tierra, de acuerdo con la legislación colombiana ${ }^{28}$.

Es el caso de las comunidades del Alto Naya, que arriban a la región despuntando los años cincuenta y que técnicamente tienen el derecho a reclamar títulos de propiedad sobre la base de una posesión que cumpliría con los requisitos exigidos por el Código Civil ${ }^{29}$, en un contexto social en el que los pobladores, indistintamente de su condición étnica, lograron construir relaciones armónicas en su vida cotidiana. Quizá por esa razón la titulación de los territorios, así como la apuesta por una figura organizativa que mediara en las relaciones entre los pobladores, no fue una preocupación latente para las comunidades. La titulación colectiva de los territorios del Alto Naya se vuelve una demanda formal de reivindicación y reparación tras la masacre y el desplazamiento masivo de 300 familias por un lapso de tres años ${ }^{30}$. La demanda, acompasada con un proceso organizativo de creación y

28 La legislación colombiana durante buena parte del siglo xx establecía que el periodo era de veinte años para reclamar título de propiedad, sobre la base de una posesión irregular. No obstante, el actual Código Civil establece que el tiempo de posesión debe ser de diez años tanto para bienes inmuebles como para bienes muebles (sobre este punto se volverá más adelante, cuando se analice el conflicto de las comunidades del Naya con la Universidad del Cauca).

29 Según el Código Civil (CC, 2003), artículo 764, la posesión puede ser regular o irregular. La primera procede de justo título y adquirida de buena fe, aunque esta no subsista después de adquirida la posesión. En consecuencia, se puede ser poseedor regular pero de mala fe o poseedor irregular de buena fe.

30 Huelga recordar que en la región hubo dos desplazamientos masivos. El primero, se registró el 24 y el 25 de diciembre entre las familias de la vereda El Ceral, entrada a la región del Alto Naya cuando corrió el rumor de una movilización de fuerzas del bloque Calima. En esa oportunidad, se desplazaron forzosamente 77 familias, alrededor de 385 personas, que se repartieron entre el resguardo de Tóez, municipio caucano de Caloto, y los municipios de Jamundí y Santander de Quilichao. El segundo desplazamiento se produjo tras la incursión de abril de 2001, cuando llegaron a la región 500 hombres del bloque Calima. Igualmente, las familias desplazadas se ubican en un albergue montado en la plaza de toros de Santander de Quilichao y en la cabecera municipal del corregimiento de Timba, departamento del Valle. 
consolidación de cabildos y juntas de acción comunal, encuentra, no obstante, tres grandes obstáculos: una disputa jurídica con la Universidad del Cauca por la propiedad del territorio, la cohabitación de tres grupos étnicos en la parte alta del Naya y la injerencia de los grupos insurgentes en los procesos sociales y organizativos.

\section{Las disputas jurídicas con la Universidad del Cauca}

A pesar de ser uno de los enclaves con mayor concentración y arraigo de población en el Pacífico colombiano, la cuenca del río Naya no obtuvo titulación por el Estado colombiano (García y Jaramillo, 2008, p. 18). Aunque sus pobladores tienen una posesión histórica del territorio que, en el caso de las comunidades afrodescendientes data del siglo XVII y en el caso de los indígenas, se remonta a más de setenta años, el primer obstáculo que tienen que sortear las comunidades es una disputa jurídica con la Universidad del Cauca, que reclama la titulación del territorio a su favor a partir de un derecho minero otorgado por el general Francisco de Paula Santander en $1827^{31}$, como prenda de garantía de deudas que se ocasionaron durante la Independencia con lo que, en esa época, era el Colegio Mayor del Cauca. Como lo recuerda Efraín Jaramillo:

Se trata de un derecho no utilizado en dos siglos ni reivindicado sino al momento de iniciarse el proceso de titulación colectiva del Naya. La ilógica pretensión de la universidad ha debido justificarse éticamente con un supuesto interés ecológico por la creación de un corredor biológico que uniría los parques naturales de Munchique en el Cauca y Farallones de Cali en el Valle. (García y Jaramillo, 2008)

La insólita reclamación de la Universidad del Cauca se produjo el 11 de septiembre del año 2000, por una solicitud de las comunidades

31 El derecho fue confirmado, como adjudicación, por la Ley 95 de 1994 y ratificada por la Resolución 332 del 23 de julio de 1955 (García y Jaramillo, 2008, p. 19). 
afrodescendientes del Bajo Naya, que en diciembre de 1999 tramitaron ante el entonces Instituto Colombiano de Reforma Agraria (Incora) la titulación colectiva de doscientas mil hectáreas, con base en lo estipulado por la Ley 70 (1993) y el decreto 1745 (1995). Ahora, el entuerto jurídico que ocasiona la reclamación de la Universidad tiene una consecuencia precisa para las comunidades: retrasa por más de una década cualquier posibilidad de titulación colectiva, ahondando las condiciones de vulnerabilidad de los comuneros que habitan ancestralmente la región:

El otorgamiento del Título Colectivo como reconocimiento legal de nuestra propiedad ancestral, se convertiría en un mecanismo de prevención de nuevos desplazamientos forzados que pueden ser ocasionados por el conflicto armado, las acciones de las personas y entidades foráneas y por la ausencia de seguridad efectiva de permanencia de nuestra etnia, quienes no concebimos nuestra existencia sin el Territorio y el uso ancestral en él, como fuente de nuestra subsistencia y pervivencia como pueblo afrodescendiente. (Isabelino Valencia R., notas de campo, mayo de 2012)

Después de trece años de discusiones y alegatos jurídicos entre la Universidad, las comunidades y las entidades públicas, el proceso técnico-jurídico adelantado en varias instancias judiciales fue desvirtuando las pretensiones de la Universidad del Cauca, según una norma que demostró la prescripción de cualquier derecho que en algún momento ostentó y por el derecho ancestral de las comunidades sobre el territorio ${ }^{32}$.

La salida jurídica, entonces, optó por una extinción del derecho de dominio, permitiendo que el territorio de la región del Naya se convirtiera en propiedad del Estado colombiano; esa nueva condición posibilitó iniciar en enero de 2013 la titulación colectiva de las tierras del Naya. El proceso, en cabeza del Instituto Colombiano de Desarrollo Rural (en adelante Incoder), se inició con la titulación de noventa mil

32 La discusión jurídica llegó a la Corte Constitucional que, a través de la Sentencia T-909 de 2009, conminó al Estado a reconocer el derecho de titulación colectiva a favor de las comunidades afrodescendientes e indígenas de la región del Naya, sobre la base de una posesión ancestral. 
hectáreas a favor del Consejo Comunitario de la comunidad negra del Río Naya, así como la ampliación del resguardo de Joaquincito ${ }^{33}$.

En síntesis, el reconocimiento cobija a las comunidades del Medio y Bajo Naya, porque la titulación de la parte alta tiene que enfrentar un nuevo escollo: la cohabitación de tres grupos étnicos.

\section{Tres grupos y un mismo territorio}

Como se ha indicado, el poblamiento de la parte alta de la región del Naya se dio mediado por contingencias que obligaron a que aborígenes, afrodescendientes y campesinos colonos establecieran una cohabitación armónica, afianzada en relaciones de parentesco, compadrazgo y vecindad, que no implicó en principio la intención de contar con un título que ratificara su derecho sobre la tierra. Como bien lo señala el antropólogo Jaime Arocha (1992; 1993; 2001), situaciones similares se pueden rastrear históricamente en buena parte del Pacífico colombiano, como resultado de un proyecto de integración nacional que, con base en la constitución de 1886, buscó homogenizar un país que construyó su identidad según el mito de un "mestizaje" que endulzaba las diferencias mediante un blanqueamiento del "otro" llamado indio o negro, consolidó prácticas de violencia e inequidad para grupos culturales minoritarios $^{34}$ (Wade, 2003, p. 273; Rivera Cusicanqui, 2010,

33 De acuerdo con el Incoder, la titulación colectiva beneficia a 18570 personas, aproximadamente, representadas en 3780 familias de 52 comunidades, ubicadas en los departamentos del Valle (municipio de Buenaventura) y del Cauca (municipios de Buenos Aires y López de Micay). La ampliación del resguardo beneficia a 220 personas, 55 familias, del pueblo eperara siapidara, ubicadas en el corregimiento de Puerto Merizalde, municipio de Buenaventura, departamento del Valle.

34 Para Claudia Briones (1998), raza o etnicidad son presentadas como realidades per se, que justifican las estrategias de segregación y control de grupos sociales por las políticas coloniales que permiten, incluso, prever la textura de las eventuales demandas (p. 42). Por su parte, Silvia Rivera Cusicanqui (2010) analiza el "mestizaje" como una categoría sobre la cual reposa el "mito nacionalista de una comunidad territorial que moderniza y sustituye las arcaicas comunidades de parentesco" (p. 69). 
p. 72; Briones, 1998, p. 42). De ahí que la Asamblea Constituyente que produjo la carta política de 1991 le apuesta a un nuevo proyecto de Estado-nación que, distanciado de la integración y la segregación de las diferencias, reconoce la diversidad étnica y cultural como principio de un proyecto que aún intenta quebrar la exclusión, el racismo y la discriminación (Pineda, 1997, p. 108; Castillo, 2007, p. 235; Pulido, 2010, p. 262).

En lo que atañe a los territorios ancestrales, el reconocimiento constitucional del resguardo como entidad territorial y del consejo comunitario como figura jurídica para la titulación de las comunidades negras permitió pensar en la consolidación de unos derechos que, por un lado, pusieran freno a la usurpación del territorio y de sus recursos por distintos actores y, por otro, aclarara las ambigüedades sobre los dominios territoriales entre indígenas y afrodescendientes, para dar paso a la formación de entidades territoriales (Arocha, 1998; Sánchez, Roldán y Sánchez, 1993). Pero los avances constitucionales no fueron suficientes para contrarrestar la usurpación de los territorios, con estrategias que convirtieron el desplazamiento forzado y masivo en artefacto de guerra para que los territorios de indígenas y negros se convirtieran en baldíos y, en algunos casos, tensionaron aún más las relaciones entre indígenas y afrodescendientes, al punto que desataron conflictos interétnicos que afianzan lo que Arocha y Friedemann (1993) denominan asimetrías étnicas.

La posición de Arocha señala que esa asimetría étnica ocurre cuando, en el horizonte de integración nacional que proyecta la constitución de 1886, se expide la Ley 89 (1890), que reconoce a las poblaciones aborígenes como salvajes que pueden mantener su autonomía territorial y poder local mientras son civilizados por las misiones cristianas. Para Arocha (1992), esa condición definió en la percepción del colombiano un "nosotros" frente a unos "otros": el indígena. Con la constitución de 1991, si bien hubo un reconocimiento de cuatro grupos étnicos (pueblos indígenas, afrodescendientes, gitanos o rom y raizales de las islas de San Andrés y Providencia), este reconocimiento no fue simétrico porque a la población indígena se le otorgó autonomía territorial (resguardo) y política (cabildos), mientras a las comunidades afrodescendientes los cobijó un artículo transitorio, el 55 de la 
constitución, que conminaba a que el Estado en los dos años siguientes a la vigencia de la constitución, estableciera una comisión especial para que, a través de una ley, se reconociera la titularidad de los territorios baldíos en las zonas ribereñas de las cuencas del Pacífico, lo que tuvo como resultado la Ley $70(1993)^{35}$. Sin desconocer que el argumento de Arocha resulta más que posible, a la luz de la constitución de 1991, más importante aún es admitir que la discusión en torno al reconocimiento de las identidades de los grupos étnicos, en especial indígenas y negros, trasciende el ámbito de una coyuntura nacional, para inscribirse en una discusión más amplia que, en los países latinoamericanos, implicó la incorporación de políticas de multiculturalismo, ancladas a la reconfiguración de las relaciones políticas y económicas que impone la agenda del modelo neoliberal (Briones, 1998; Segato, 2007; Ng'weno, 2007; Pulido, 2010; Jaramillo, 2011). Por otra parte, la voraz y despiadada violencia que experimentan las comunidades de la costa Pacífica colombiana por el control y el dominio de sus territorios (Almario, 2004, p. 73; Jaramillo, 2011, p. 176) permite inferir que las tensiones interétnicas entre indígenas y negros, incluso intraétnicas entre indígenas y negros con campesinos colonos, sean un problema menor. Cabe señalar que el asesinato, el desplazamiento, la desaparición forzada o el abuso sexual ${ }^{36}$ son dispositivos de un repertorio de vio-

35 En el fondo, el reclamo de Arocha (1992) es frente a los líderes indígenas -Francisco Rojas Birry en representación de la Organización Nacional Indígena de Colombia (Onic), Lorenzo Muelas Hurtado en representación del Movimiento de Autoridades Indígenas de Colombia (Aico) y Alfonso Peña Chepe en representación del desmovilizado grupo insurgente Quintín Lame, quien tuvo voz pero no voto en las discusiones- que participaron en la Asamblea Nacional Constituyente como escenario en el que se construyó la nueva carta política. Según Arocha, ellos no garantizaron en igualdad de condiciones los derechos de las comunidades negras respecto a las comunidades indígenas (1993, p. 118). Esta posición desató prolijas discusiones con el sociólogo Orlando Fals Borda, quien también participó de la Asamblea Nacional Constituyente. Más recientemente las discusiones son con el antropólogo Luis Guillermo Vasco. Sobre el particular, véase el trabajo de Hernando Andrés Pulido (2010).

36 El abuso sexual, el maltrato físico y psicológico y las formas de esclavización han sido frecuentes en el conflicto armado en Colombia. Siendo el miedo el 
lencia por los intereses de esa agenda geopolítica y geoeconómica que trae consigo el modelo neoliberal (Villa y Houghton, 2004).

En la región del Alto Naya, estas discusiones son distantes aunque no ajenas. Como lo afirmé párrafos atrás, a lo largo de más de tres décadas se construyeron relaciones estables y armónicas, pues los cultivos de coca están en su origen étnico. Para los pobladores del Alto Naya, esa armonía comienza a romperse cuando el negocio de los cultivos de coca se convierte en la principal actividad económica y trastoca la dinámica social y política de la región. Según los pobladores, a esta situación también contribuyó la llegada de los paramilitares del bloque Calima a comienzos del año 2000 —en un movimiento estratégico de las Auc para dominar el sur del departamento del Valle y el norte del Cauca一:

Pero no es porque tengamos problemas con los negros o con los colonos, es porque comienzan los retenes, el control a la población, la militarización de lo nuestro: “¿para dónde va?, ¿qué es lo que trae?, ¿quién son sus vecinos?”. También comienzan los asesinatos... un muerto, dos o tres por noche. Los paras hacían recorridos a las veredas dizque buscando milicianos. Lo más grave es que empiezan los rumores sobre descuartizamientos... cuerpos arrojados al río, un miedo siempre ahí. Por eso para nosotros la masacre comenzó en el 2000, aunque la incursión grande fue en abril de 2001. (Elvira Cundé, notas de campo, septiembre de 2013)

A mi modo de ver, solo en ese momento los pobladores del Alto Naya se plantean la importancia de tener un título sobre la tierra, entendiendo que la avanzada paramilitar tenía intereses económicos que

dispositivo de control predominante de todos los actores armados, incluyendo las bandas criminales que se han organizado tras la desmovilización de los paramilitares, recién los testimonios y relatos de personas víctimas, especialmente mujeres, han comenzado a irrumpir en instancias de Justicia y Paz, pero también en proyectos académicos independientes. Especialmente destaco los informes El día que se dañó la tranquilidad. Violencia sexual en las masacres de La Gabarra y el Alto Naya (Céspedes, 2011) y Comisión de verdad y memoria de mujeres colombianas. La verdad de las mujeres víctimas del conflicto armado en Colombia (RPM, 2013). 
encuentran en el control militar el dispositivo para causar miedo que media las relaciones en la región, desde el control de la producción y comercialización del cultivo de hoja de coca, pasando por la emergencia en la explotación ilegal de minerales, hasta el desarrollo de megaproyectos relacionados con madera y energía ${ }^{37}$. El desplazamiento forzoso que tuvieron que vivir durante más de tres años, en el que se propició un ejercicio necesario de empoderamiento político que dio lugar a la creación de una escuela interétnica como escenario de encuentro, discusión y formación, permitió que el reclamo de solicitud sobre el derecho a la titulación como el principal acto de reparación se encarara colectivamente, es decir, como pobladores de la región, lo cual permitió trascender en el agenciamiento divisiones y discusiones de tipo étnico. Distinguir la reivindicación sobre la base de un derecho ancestral que no enfatiza en la etnicidad fue el factor que garantizó en principio zanjar fracturas entre las comunidades. Conscientes de que la titulación estaba fundada en una reivindicación histórica y ancestral, la estrategia llevó a que los pobladores propusieran la titulación de un territorio interétnico que, además, respondía a una configuración

37 De hecho, la violencia ejercida por insurgentes, paramilitares, bandas criminales y fuerza pública ha opacado otro tipo de conflictos relacionados con la agenda económica. El más problemático, a mi modo de ver, ha sido con la transnacional papelera Smurfit Cartón de Colombia, propiedad del Jefferson Smurfit Group, que llegó a la región en 1978 para sembrar pinos y eucaliptos en la vereda La Paila, municipio caucano de Buenos Aires. El tipo de árbol sembrado y la técnica de corte total (tala rasa) han sido un factor devastador para el frágil ecosistema de selva pluvial tropical, lo que propició fuertes enfrentamientos entre las comunidades indígenas y la compañía. Precisamente, la presencia de esta motivó fuertes enfrentamientos con las comunidades nasa, que quisieron recuperar el control de las tierras cultivadas por las vías de hecho. Para minimizar los enfrentamientos, Smurfit Cartón de Colombia propició la creación de Agroforestal El Naya S.A., que convirtió a los campesinos colonos de la región en sus propietarios. El movimiento estratégico implicó que la transnacional vendiera tres fincas de su propiedad a la nueva empresa "comunitaria", para que continuara la siembra de los cultivos maderables; de paso los convirtió en contratistas proveedores. Con ello, la Smurfit Cartón de Colombia garantizó la producción maderera y se desligó de cualquier tipo de confrontación con las comunidades indígenas. En otras palabras: la estrategia puso a pelear a los aborígenes con los campesinos colonos. Para mayor información, consúltese el estudio de Joe Broderick (1998). 
territorial en la que comunidades indígenas, negras y campesinas están literalmente mezcladas.

No obstante, la iniciativa de una solicitud de titulación sobre la base de una relación interétnica no logra materializarse, dado que la legislación colombiana no considera esa figura. Cuando en enero de 2013 el Estado, a través del Incoder, decide titular el territorio del Naya, lo primero que recomienda es que las comunidades escojan de manera autónoma una de las tres figuras jurídicamente viables: resguardo, consejo comunitario de comunidades negras o zona de reserva campesina. El consejo comunitario quedó descartado desde un comienzo, teniendo en cuenta que el nivel de población negra en la parte alta es muy baja, donde, además, buena parte de la población negra se autorreconoce como campesina. La escogencia, entonces, estaría inclinada a la figura del resguardo, teniendo en cuenta el trabajo político y social adelantado por la escuela interétnica, sumado al peso de la tradición del pueblo nasa; pero la injerencia de las Farc-EP en el proceso fue un tercer obstáculo, pues el grupo insurgente presionó a las comunidades para que eligieran una figura legal y novedosa en el ordenamiento territorial colombiano: las zonas de reserva campesina.

\section{El control territorial de las Farc-EP}

La relación entre los pobladores del Alto Naya con los grupos insurgentes (Farc-EP y ELN) ha sido de una cohabitación estratégica. Desde la perspectiva de los pobladores, se respetan unas fuerzas armadas que, ante la precaria presencia del Estado, ejercen el control en la zona. Este, no obstante, se ejerce en medio de la resistencia de las comunidades que buscan contrarrestar la injerencia sobre los procesos sociales y comunitarios en los cuales los comuneros buscan ejercer el derecho a la autonomía que les asiste sobre sus territorios. Esta relación ha tenido momentos álgidos — por ejemplo, cuando los insurgentes imponen multas o sanciones, que incluyen destierros y ejecuciones-, que animan a las comunidades a fortalecer procesos organizativos con tres dinámicas: primera, recuperación de tradiciones propias del pueblo nasa para fortalecer sus identidades que, según palabras de los líderes, siempre han estado "amenazadas"; segundo, procesos de autorreconocimiento 
de campesinos y negros como indígenas, así como pobladores negros que se autorreconocen como campesinos, en marcos que despliegan tácticas políticas y sociales para alcanzar en mejores condiciones las demandas de titulación del territorio; tercera, la conciencia política e histórica respecto a que el territorio es el eje de la vida comunitaria, aspecto que trasciende la coyuntura política (Rappaport, 2000, p. 167), lo que permite construir una identidad como "pobladores" que apelan a todos los recursos disponibles para alcanzar un propósito común: la titulación.

Sobre estas dinámicas hablaré cuando aborde los procesos de la escuela interétnica y de Utinaya, que son la condición para que en 2013 se adelante un proceso de consulta entre los pobladores, para escoger la figura legal sobre la cual se quiere que el Estado haga la titulación colectiva. Por ahora, me interesa referir que, en el marco de ese proceso de consulta, aparece un tercer obstáculo que enfrenta las comunidades con las Farc-EP. El enfrentamiento se registra cuando las comunidades, en el desarrollo de su autonomía como pobladores del territorio del Alto Naya, deciden que la titulación se haga mediante la figura del resguardo. Las Farc-EP, en principio, desconocen la decisión y presionan para que se opte por la figura de la zona de reserva campesina (en adelante ZRC).

Esta última es una figura territorial amparada por la Ley 160 (1994), que establece que el Estado, a través del Incoder, podrá adjudicar zonas catalogadas como baldías para fomentar procesos de colonización y garantizar la pequeña propiedad campesina, teniendo en cuenta características agroecológicas y socioeconómicas (artículos 79 y 80). No obstante, los editoriales de los periódicos han asociado a las ZRC con las Farc-EP. Esta figura toma fuerza cuando el grupo insurgente -al comienzo de los diálogos con el gobierno de Juan Manuel Santos en Cuba- propuso la creación de 59 zonas de reserva, con una extensión aproximada de 9 millones de hectáreas. Esa representación apunta a que las ZRC serían escenarios que las Farc-EP convertirían en fortín político y social, producto de una reconfiguración de las estrategias de lucha, que también incluyen la emergencia de un partido político - la Marcha Patriótica-. Al respecto, sostiene el influyente columnista del periódico El Tiempo, Plinio Apuleyo Mendoza: 
En aras de su nueva estrategia, no es descartable que las Farc busquen el cese del conflicto armado, pero a condición de venderlo como quien quiere salir de un carro viejo, tratando de lograr por él el mejor precio posible. Este carro viejo — la lucha armadaya no le sirve para la toma del poder. El Gobierno, por su parte, intenta no pagar un precio muy alto por esa compra y ganar con ello la vistosa lotería política de un acuerdo de paz. El mundo, de su lado, puede recibirlo de una manera muy positiva. Pero el riesgo de este desenlace es el de encontrarnos con unas Farc dueñas de amplias zonas del territorio, con un partido político de insospechada fuerza (la Marcha Patriótica) y la posibilidad de que, como ocurrió en Venezuela, Bolivia y Ecuador, aparezca en el panorama electoral un outsider, aparentemente inofensivo, capaz de abrirles las puertas del poder. Tal es el riesgo que debemos ver de frente, sin olvidar que las Farc están moviendo nuevas y peligrosas fichas en su tablero para alcanzar, sin pausa y sin prisa, su supremo objetivo. (2013)

Para los líderes que encararon el proceso de consulta, la escogencia de la figura del resguardo respondió a una lectura estratégica tanto del escenario local como global. El ejercicio de consulta valoró las ventajas y las desventajas de cada una de las opciones de titulación consideradas por la legislación, y llegó a la conclusión de que el resguardo era la más conveniente por las garantías políticas, sociales y jurídicas que ofrece. En la perspectiva local, he mencionado que el resguardo es una entidad territorial reconocida por la Constitución, que permite, por un lado, que las comunidades puedan acceder a lo que la legislación colombiana denomina Sistema General de Participaciones (Ley 715 de 2001), mediante la cual el Estado transfiere recursos para la financiación de servicios de salud, educación, agua potable y saneamiento básico $^{38}$. Por otro lado, respecto al reconocimiento de la autonomía, el artículo 246 de la Constitución (CP, 1991) también faculta a las

38 Esa transferencia se desprende de un mandato constitucional, pues el artículo 357 establece que los resguardos, como entidades territoriales, deben acceder a los recursos del Estado. 
autoridades indígenas a administrar justicia en sus territorios, de acuerdo con sus usos y costumbres.

Por sus alcances jurídicos, el resguardo también resulta una figura conveniente en el plano global-neoliberal, puesto que los pobladores son conscientes de que se ciernen intereses geoeconómicos sobre la región, sobre todo en lo que atañe a proyectos minero-energéticos. En este sentido, la figura del resguardo, a diferencia de una zona de reserva campesina, goza de la garantía constitucional de la consulta previa, entendida como instrumento de protección de los derechos de los pueblos aborígenes y tribales. La consulta previa tiene su origen en el convenio 169 de la oIT (1989), que obliga a los Estados que lo suscriben ${ }^{39}$ a consultar a las autoridades tradicionales de las comunidades indígenas y negras cuando se van desarrollar en sus territorios proyectos cuyo impacto ponga en riesgo los derechos colectivos de los pobladores (MacKay, 1999, pp. 20-22) . $^{40}$

Sobre esta doble lectura los comuneros de la región del Alto Naya toman una decisión que no es compartida y respetada por las Farc-EP,

39 El convenio es suscrito por el Estado a través de la Ley 21 (1992), y se convirtió en el instrumento más empleado por las comunidades indígenas y negras para garantizar sus derechos colectivos. Por eso, se ha generado un interesante y prolijo debate en el que se expresan las representaciones en torno a la noción de "desarrollo" como reino de abundancia (Escobar, 1998, p. 21), siendo la consulta previa un instrumento que entorpece el "progreso". Los grupos indígenas y negros son considerados por algunos como los "enemigos" por antonomasia del desarrollo cuando apelan a tal mecanismo, en una representación discursiva que estima que debería primar el interés general de la nación sobre el interés particular de grupos étnicos minoritarios (Reyes y Martínez, 2013).

40 Para Claudia Briones (1998), la lucha de los pueblos indígenas por la libre determinación política, la autonomía de los territorios y el control de su desarrollo económico es lo que viene dinamizando la discusión en torno a nuevos conceptos y enfoques de los derechos humanos, lo que promueve la emergencia de una cuarta generación de derechos. Como sujetos políticos y culturales sui generis, los intereses de los pueblos indígenas suelen trascender las fronteras de los estados nacionales soberanos, con la conciencia de ser pueblos subordinados cuya existencia depende de reclamos morales (en diálogo con la categoría de E. P. Thompson de economía moral) que desafían la estructura y los valores del "primer mundo". 
puesto que el resguardo se entiende como la forma jurídica que legitimaría aún más la autonomía territorial de unas comunidades que, continuando con la posición asumida por los pueblos indígenas del Cauca respecto a la confrontación armada, rechazan la presencia de cualquier actor armado, incluyendo la fuerza pública ${ }^{41}$. De ahí las presiones y amenazas de las Farc-EP durante 2013 para que la decisión fuera modificada. No obstante, la conciencia política e histórica de los pobladores hizo que la decisión se respetara. En la actualidad, los pobladores del Naya están a la espera de que el Incoder reinicie el proceso de titulación. Pero ¿cómo se llega a ese proceso de unificación? ¿Cómo logran las comunidades despojarse de las marcaciones étnicas para iniciar un nuevo proceso de reconocimiento comunal? ¿Qué dinámicas sociales y políticas permiten sortear y agenciar las presiones de las Farc-EP?

\section{La apuesta por un territorio interétnico}

Una década después de perpetrada la incursión paramilitar por el bloque Calima — que derivó en el asesinato de una veintena de comuneros (según la Fiscalía) y un éxodo masivo que obligó a las familias a vivir por más de tres años fuera del territorio- muchos pobladores de la región del Alto Naya se reconocen como una comunidad que comparte el recuerdo doloroso de una Semana Santa sangrienta. Y cuando los recuerdos ahondan en el pasado, resulta inevitable reconocer la estela de violencias que, generación tras generación, han dejado profundas cicatrices, registradas en relatos que se actualizan porque, como lo reconoce Elvira, en ellos reposa la "fuerza para enfrentar demandas

41 La decisión de no permitir la presencia de ningún actor armado en los territorios indígenas, sustentada en criterios de autonomía y neutralidad, también promueve un debate cuando se trata de la fuerza pública. La discusión se complejiza cuando se registran casos en los que las comunidades y las organizaciones indígenas desalojan a los comandos del Ejército o retienen a sus miembros. El argumento central de las Fuerzas Militares, siguiendo la tesis de Max Weber, es que no hay territorio "vedado" para el Ejército, porque tienen el monopolio legítimo de la fuerza. Desde la otra orilla, las comunidades denuncian los abusos de autoridad de los militares y la complicidad entre Ejército y paramilitarismo. El caso del Naya es un ejemplo de este argumento. 
presentes". Y aunque el dolor ha sido un elemento cohesionador durante estos años, igual poder tiene el empeño por alcanzar la titulación del territorio como la más importante de las reparaciones.

En consecuencia, la masacre perpetrada en abril de 2001, como máximo evento disruptivo desencadenado por la violencia paramilitar ejercida por más de cuatro años en la región, afianza la conciencia política histórica de unas comunidades que se comienzan a reconocer como pobladores de un territorio que habitan ancestralmente. La conciencia de lo ancestral permite superar las diferencias étnicas entre los tres grupos poblaciones que cohabitan la región, lo que produce elementos distintivos para valorar las relaciones colectivas, y establecer una comunidad que se imagina cohesionada en el territorio. El autorreconocimiento como pobladores ancestrales de la región del Alto Naya hay que entenderla como producto social histórico, resultado de dinámicas políticas, económicas, sociales y culturales (Briones, 1998; Hall, 1991; Hall, 1993).

Visto desde otra perspectiva: en un país que reconoce en su Carta Política la existencia de cuatro grupos étnicos, es usual que indígenas $\mathrm{y}$ afrodescendientes sean realidades objetivas que, al mismo tiempo, se convierten en categorías analíticas. Esto es lo que ocurre en el Alto Naya, donde se parte de la premisa de aceptar que en dicho territorio cohabitan tres grupos poblacionales con rasgos étnicos y culturales que los caracterizan. No obstante, la etnicidad es una marcación social en la que están en juego prácticas efectivas que dinamizan la constitución de subjetividades y la construcción de identidades sociales. De ahí la importancia de prestar atención al tipo de marcaciones con que los grupos construyen su alteridad, entendiendo que los criterios de esa alteridad son históricos y, por lo mismo, mutables (Briones, 1998).

En ese contexto, retomo la noción empleada por Claudia Briones (1998) de aboriginalidad, característica de la antropología australiana, entendida como proceso de producción cultural de una forma sui generis de alteridad, que opera en procesos emergentes de construcción social mediante prácticas de marcación o automarcación a través de las cuales los grupos organizan sus diferencias, y propician la unificación en torno a elementos que van configurando una "identidad común”, que desdibuja especificidades étnicas, culturales, regionales e históricas. 
Los criterios de unificación también incluyen "sentimientos de unicidad" con ejercicios de selección estratégica sobre un pasado en el que ciertos momentos son recordados, mientras otros caen en el olvido. De igual forma, destaca Briones (1998) que la noción, así como lo que representa lo no aborigen, se transforma puesto que se (re)define mediante relaciones sociales y contextos históricos siempre cambiantes (1998, p. 19; 2005, p. 19) ${ }^{42}$. Señala la antropóloga argentina:

A diferencia de las nociones de etnicidad y raza, la aboriginalidad se ubica topológicamente en un cruce de caminos que es más histórico que conceptual. En consecuencia, no resulta pertinente preguntarse si la aboriginalidad se circunscribe más a grupos étnicos o grupos raciales; lo importante es indagar y analizar por las circunstancias históricas que posibilitaron que los grupos se formaran a través de marcas selectivas, complejamente biologizadas y/o culturizadas. (p. 20)

En síntesis y en un horizonte más amplio, Briones señala que desde que las expansiones coloniales convirtieron al indio en categoría social, entendiendo que lo indígena, así como lo negro, ha sido lo radicalmente distinto, lo no indígena es, en ese marco, lo no distinto respecto a unos estándares colectivos de identificación que, como otras categorías

42 Dado que el interés de Claudia Briones está en de-construir las ideas que han surgido en antropología en torno a la diferencia, se parte de la premisa de aceptar que la formación de grupos va más allá de la simple reunión de personas. Briones describe cuatro perspectivas que dialogan entre sí: 1) el significativo giro que hace Fredrik Barth (1976) al considerar que los grupos étnicos son categorías de adscripción e identificación, utilizadas por ellos mismos para construir sus propias formas de organización e interacción; por eso, más que estudiar los grupos étnicos como tipologías predefinidas, es preferible comprender los procesos que conducen a que un grupo se autorreconozca como indio o negro; 2) la noción de "comunalismo" de James Brown (1990) como formas y trayectorias de acción que promueven un sentido de pertenencia; 3) la noción "sentido del devenir" que propone Charles Taylor (1989), ligado a la consigna de Brown, y 4) la noción de "comunidad imaginada” de Benedict Anderson (1993) que muestra cómo mediante las prácticas y relaciones sociales los grupos construyen las condiciones para imaginarse como parte de una "comunidad". 
sociales, fijan inclusiones o exclusiones selectivas (Briones, 1998, p. 146). Lo cierto es que las marcaciones con las que un grupo social construye sus identidades y sus relaciones de alteridad se configuran con factores históricos particulares. Ahora bien, dialogando con la frase que Marx consignó en El dieciocho brumario de Luis Bonaparte (2003) respecto a que los hombres hacen su propia historia, pero no la hacen como les place, porque las circunstancias no fueron elegidas por ellos, sino que operan bajo circunstancias encontradas, dadas o transmitidas por el pasado, Briones también considera que en los procesos de identificación los sujetos también operan bajo circunstancias que no fueron elegidas por ellos (2005, p. 59).

Esa reconfiguración de marcas sociales ha venido ocurriendo en las comunidades del Alto Naya. El asunto se remonta al año 2003, cuando las comunidades y las organizaciones sociales que representan a indígenas, negros y campesinos deciden poner en marcha una iniciativa para construir una agenda interétnica que les permita encarar los problemas que derivaron de la masacre de abril de 2001 (especialmente lo relacionado con el desplazamiento forzado y el retorno de las familias al territorio), y también para discutir problemas estructurales relacionados con las características geoeconómicas de la región. En ese marco, nace lo que los pobladores denominaron Encuentro Interétnico del $\mathrm{Naya}^{43}$, que es un escenario de discusión y acción para la defensa y la resistencia del territorio. En total, se celebraron cuatro

43 Los encuentros contaron con el apoyo de organizaciones sociales locales, regionales y nacionales que se autodenominaron bajo el nombre de Mesa de trabajo y solidaridad con el Naya. Entre los participantes estuvieron: el Consejo Regional Indígena del Cauca (Cric), la Asociación de Cabildos Indígenas del Norte del Cauca (Acin), la Organización Regional Indígena del Valle (Orivac), el Proceso de Comunidades Negras (PCN), la Asociación de Cabildos Indígenas del Valle (Aciva), la Organización Nacional Indígena de Colombia (Onic), los Cabildos Indígenas del Alto Naya, el Comité de Desplazados del Alto Naya, el Consejo Comunitario del Naya, el Consejo Nacional Indígena de Paz, las Juntas de Acción Comunal del Naya. Entre las organizaciones no gubernamentales estuvieron: Planeta Paz, la Consultoría para los Derechos Humanos y el Desplazamiento (COHDEs), la Fundación swissaid, la Fundación para la Educación y el Desarrollo (Fedes), Corpojuridica AC, la Asociación Minga, el Colectivo de Trabajo Jenzera y las Hermanas Misioneras Lauras. 
encuentros (julio, agosto, octubre y diciembre de 2003) en un ejercicio político que obligó a que los grupos sociales que se reconocían como indígenas, negros o campesinos comenzaran a valorar, en unas realidades problemáticas comunes, unos elementos básicos de convergencia, teniendo como puente el territorio. De acuerdo con el acta que se elaboró tras el encuentro, el objetivo principal fue

llegar a establecer unos criterios comunes para trabajar en el fortalecimiento de las organizaciones propias de las comunidades (Consejos Comunitarios, Cabildos Indígenas, Juntas de Gobierno Comunal) y crear un liderazgo interétnico que, como organización propia y autónoma, oriente la resistencia, defienda los territorios, retorne a los desplazados del Naya y siente las bases para un desarrollo integral de la región.

Un primer aspecto vital que se deriva de las discusiones fue representar al territorio del Naya como un cuerpo humano que asume al río como su columna vertebral, y une con sus afluentes las diferentes regiones. La cuenca del río es proyectada como unidad ambiental, territorial y social que, ante cualquier actividad económica extractiva en las actividades minera, agropecuaria o industrial, afecta negativamente el ecosistema. Por esto, los participantes asumen que, en su calidad de pobladores ancestrales, son "autoridades" ambientales encargadas de velar por la conservación y la protección de los derechos de propiedad colectiva, y garantizar la integridad de los territorios. Aunque ese mandato es atribuido a indígenas y negros, en la participación de los asistentes comienzan a surgir declaraciones de autorreconocimiento (Barth, 1976, pp. 11-17) en la que algunos pobladores negros se sienten campesinos y varios pobladores campesinos se sienten indígenas. De igual forma, la postura respecto a que los participantes se autodeclaren "pobladores ancestrales del territorio" indica la (re)configuración de la marcación social, puesto que las dinámicas de poblamiento evidencian que los indígenas nasa arriban a la región a mediados del siglo pasado, mientras los campesinos llegan en distintos momentos en pequeñas oleadas de migración.

Por otra parte, el encuentro también permite que los grupos concreten una agenda de trabajo que prioriza los siguientes temas: 1) gobierno 
y justicia propia, ligada a la autonomía de los territorios indígenas; 2) ordenamiento territorial espacial, social, económico y político; 3) administración del territorio respecto al manejo de los recursos naturales; 4) discusión sobre las posibles formas de propiedad: resguardos, territorios colectivos o reservas campesinas; 5) usos del suelo en relación con aspectos productivos y, sobre todo, soberanía alimentaria, y 6) servicios básicos en educación, salud y vivienda.

En el acta de la reunión, se concluye que la Agenda Interétnica sienta los fundamentos para la proyección de la institucionalidad que permita asegurar la propiedad del Naya a afrocolombianos, indígenas y campesinos. Señala el documento que la agenda responde a

los esfuerzos que estamos haciendo los pobladores de esta región por escapar a la violencia y por construir formas de tolerancia, solidaridad y participación. Con esta nueva institucionalidad que queremos construir, no nos estamos movilizando en contra de nadie. Es una apuesta en favor de la vida pero son espacios de convivencia y tolerancia que por naturaleza son una resistencia a la violencia.

En los siguientes tres encuentros, las discusiones derivan en "apuestas" políticas de hondo calado, traducidas en dos temas paradigmáticos en la medida en que interpelan los marcos normativos en lo que respecta a la tierra en el país: la propuesta de que en una eventual reparación centrada en la titulación colectiva se reconozca la región del Naya como territorio interétnico, acompañada por la formación a través de una escuela interétnica. La agenda toma fuerza en el segundo encuentro interétnico, en el cual la participación del sector campesino fue decisiva porque se pudieron expresar preocupaciones concretas en torno al territorio. Se acepta que el grupo mayoritario en la región es la población indígena, los campesinos manifestaron el temor de que se desconocieran los derechos adquiridos sobre la tierra: "En caso de que se constituya un resguardo indígena, preocupa que los cabildos quieran ponerle precio a la tierra, comprarlas y sacarnos del territorio" (Pablo, notas de campo, septiembre de 2013). 
De acuerdo con las actas del encuentro, la respuesta fue contundente:

El territorio no es una "marrana (un cerdo) para repartir". El territorio es para los indígenas, campesinos y negros una fuente de subsistencia y por lo tanto todos los pobladores tienen unos deberes para mantener este territorio al margen de cualquier proceso de destrucción.

De igual forma, en las discusiones se aclaró que en la región ningún grupo contaba con títulos de propiedad, y acotan que, en el ámbito jurídico, había una posesión de buena fe sobre un terreno al que se le habían efectuado mejoras. Por ello, el encuentro centró la discusión en concretar estrategias que permitieran una apropiación legal del territorio, fijando acuerdos en torno al buen manejo y uso de los ecosistemas de la región; establecer criterios sólidos para un desarrollo integral de la región; e impulsar una economía propia para garantizar a todas las comunidades la soberanía alimentaria.

Conscientes de que los acuerdos y las agendas debían contar con un órgano de acción-representación, los pobladores materializaron la creación de la Unión Territorial Interétnica del Naya (en adelante Utinaya) con los siguientes principios ${ }^{44}$ : todos los grupos deben estar representados en igualdad de condiciones; construir organización y gobierno es un asunto de todas las personas, familias y grupos; que todos tienen responsabilidades frente a este órgano de gobierno; transparencia en el manejo de los recursos; respaldo comunitario a la organización. En esta organización social colegiada, se discutieron tres asuntos que las comunidades consideraron relevantes:

a. el problema de la producción en el territorio, puesto que la preponderancia que tomó el cultivo de la coca, acompañada con la significativa disminución de cultivos propios produjo un problema generalizado de desnutrición de la población infantil

44 Los participantes sabían que proyectar las demandas en una sola organización no era tarea sencilla, por lo que se decidió que a la primera junta directiva de Utinaya se le otorgara un año de "amañe" o "enamoramiento" para "ganar" confianza, sobre todo con las comunidades. 
y adulta. Esta situación fue agravada por los altos costos del transporte de alimentos que son trasladados por el camino de herradura que conecta al Alto Naya con la población de Timba, que es la más cercana, en una jornada de más de doce horas de recorrido a pie. Al respecto, los participantes del tercer encuentro sostuvieron en el acta:

Actualmente se está sembrando y produciendo solo coca, ello se debe a las buenas condiciones de la zona para este cultivo. Los demás productos como el plátano, maíz, fríjol, yuca y frutales son difícil de comercializar. Es por eso que la economía de la región depende de los cultivos de coca. La mayoría de los alimentos se traen de afuera.

b. El manejo ambiental, pues se reconoce que las prácticas de ciertas actividades económicas extractivas han propiciado la contaminación de las fuentes de agua, lo que incide en la salud de los pobladores, y también en la muerte de peces, principal fuente proteínica de la población.

c. El fortalecimiento organizativo de Utinaya, los cabildos, las juntas comunales y los consejos comunitarios de comunidades negras, acompañado de un trabajo de formación política.

Sobre estos tres ejes, los participantes del encuentro hicieron un diagnóstico de la situación de las comunidades en relación con el territorio, en aspectos ligados a la producción agropecuaria y el levantamiento de un censo poblacional, tarea que requirió el conocimiento que los líderes tenían sobre el número de familias existente en sus respectivas veredas. La discusión se dinamizó a través de tres cuestionarios que, respecto al fortalecimiento político, indagó, por primera vez, sobre las posibles ventajas y debilidades que tendría una organización interétnica como escenario de mediación y agenciamiento. El debate en la mesa en la plenaria permitió expresar tres intereses sentidos, que conforman una postura conjunta en torno a un territorio compartido: 
a. El interés por fomentar la formación de los dirigentes, con la posibilidad de crear una escuela interétnica.

b. Conocer y dominar las normas, especialmente las referidas al tema territorial, para construir y proyectar estrategias frente a las demandas y las reivindicaciones.

c. Si bien la lucha por el territorio no debe desconocer las leyes y normas, tampoco se puede ignorar la importancia de las tradiciones y las costumbres que darían pie a un derecho consuetudinario sobre un territorio que comienza a reconocerse como la "casa" de todos los grupos, siendo la interculturalidad la proyección de una nueva marcación social.

Sobre esta nueva marcación social, se discute la idea de un territorio interétnico, conscientes de que en la legislación colombiana no existe una figura jurídica que habilite una titulación colectiva por esta vía. Pero como lo recuerda el antropólogo Efraín Jaramillo: “el objetivo, entre muchos otros, era precisamente ése: decirle al Estado que las 'realidades' de las comunidades indígenas, campesinas y negras están más allá de las normas y las leyes” (Efraín Jaramillo, notas de campo, abril de 2012).

La concepción de un territorio interétnico es una propuesta basada en una estrategia de resistencia que ha caracterizado las dinámicas políticas y sociales del pueblo nasa. De acuerdo con los estudios de Rappaport (2000; 2005), las concepciones históricas de los nasa están sustentadas en dos aspectos: por un lado, la reapropiación consciente del pasado que se impregna con dinámicas políticas, sociales y económicas; por otro lado, la reinvención de una tradición que adapta estratégicamente modelos pasados a circunstancias sociales nuevas (2000, pp. 17-18).

Para este autor, la historia del pueblo nasa es una forma de conocimiento sobre los orígenes de ciertas situaciones que se traducen en una relación de subordinación social a la que es preciso resistirse y se debe transformar, con el fin de obtener información para reivindicar derechos que deben encararse en el marco legal vigente. Esas formas de conocimiento también sirven para incorporar nuevas definiciones sobre sí mismos como pueblo aborigen. En palabras de Rappaport (2000): 
La conciencia histórica de los habitantes de Tierradentro se funda en un vínculo moral con el pasado, cuyo objetivo práctico es conseguir fines políticos en el tiempo presente... La historia nasa tiene su propia lógica interna que se encarna en antiguos modelos reformulados, siglo tras siglo, para enfrentar nuevas circunstancias políticas. (p. 37)

Ese vínculo moral con el pasado no desdeña los aspectos normativos que enmarcan las reivindicaciones presentes del pueblo nasa. Rappaport recuerda que la "verdad histórica" es meramente descriptiva mientras la "verdad legal" tiene un carácter performativo que tiende a convertirse en histórica —es lo que ocurre con la sentencia judicial que se transforma en documento histórico, en un procedimiento que edita o que ocluye las voces de quienes participaron en una causa. Rappaport (2000) recorre, entonces, una ruta distinta al estudiar documentos históricos en los que reposa lo que los nasa reconocen como "evidencias", que luego son empleadas para incidir en el plano jurídico. En otras palabras, la verdad histórica se convierte en verdad legal, en una metamorfosis en la que los nasa - a través de sus líderes e historiadores nativos ${ }^{45}$ - utilizan la palabra escrita como una fuerza contrahegemónica para reivindicar sus derechos, especialmente territoriales (p. 21).

Es el caso del cacique Juan Tama del siglo XviII, quien dejó abundantes documentos, sobre todo jurídicos, los cuales defienden la legalidad de los territorios del pueblo nasa. Sostiene Rappaport (2000) que, a medida que líderes de tiempos más recientes leyeron y releyeron los documentos que dejó Tama para hallar pruebas escritas que legitimaran las nuevas aspiraciones territoriales, se fue tejiendo una historia de lucha y resistencia, transmitida oralmente de generación en generación.

45 El estudio de Rappaport (2000) se centra en la figura de tres emblemáticos líderes nasa - Juan Tama, Manuel Quintín Lame y Julio Niquinás- quienes han venido alimentando el pensamiento de su pueblo a través de una ideología y un lenguaje que ha facilitado el proceso de descolonización, propiciando un campo conceptual que posibilita valorar de manera crítica los sistemas de creencia nasa, así como tener una postura propia acerca de la naturaleza de la dominación colonial, base para proyectar estrategias de resistencia (p. 25). 
En un horizonte más amplio, considera Rappaport que a través de los siglos la concepción histórica de los nasa cumple el papel de una narrativa fundacional del proceso de etnogénesis, mediante la cual se definen y configuran como grupo étnico.

Por otra parte, en los ejercicios de memoria, subyacen estrategias de resistencia que, además de darle sentido al pasado en función de intereses presentes, incorporan los sentidos construidos con un territorio - la región de Tierradentro-, que es sagrado, pero que también otorga la razón de ser porque es el lugar en el que se vive, se cultiva, se camina... En consecuencia, su defensa es indiscutible. Las estrategias de resistencia, entonces, incluyen: la recuperación de tierras; la promulgación de derechos en los terrajeros; el fortalecimiento de la autoridad del cabildo, y la revitalización de la cultura y de la lengua. En otras palabras, los sentidos en torno al pasado son una estrategia de resistencia para el presente, producto de una conciencia histórica y política (Rappaport, 2000, p. 37).

De ahí que en el último de los encuentros interétnicos - que se desarrolla con el propósito de legitimar los acuerdos alcanzados en los tres eventos anteriores, fijando como principal meta, según acta fechada el 15 de diciembre de 2003, "el aseguramiento legal del territorio" para la formulación de "planes de desarrollos sostenibles"-, y en esta forma la discusión informal en torno a una eventual propuesta de titulación de un territorio interétnico tuvo acogida entre los participantes. No obstante, el encuentro será el preludio de una gran frustración, cuando la política de reparación individual propuesta por el Estado se combina con la mezquindad de algunos dirigentes que prefirieron optar por las indemnizaciones civiles-monetarias de carácter individual, mucho más rápida en términos administrativos, que apostar por una reparación colectiva e integral. Recuerda el antropólogo Efraín Jaramillo:

Con la agenda interétnica se estaban colocando los fundamentos para desarrollar una nueva institucionalidad que posibilitara asegurar la propiedad del Naya a negros, indígenas y campesinos, y que valorara los esfuerzos que estaban haciendo los pobladores de esta región por escapar a la violencia y por construir formas de 
tolerancia. Solidaridad y participación. Construir una institucionalidad propia que estableciera las bases para un desarrollo económico y un manejo ambiental apropiado y generoso con la naturaleza. Con esta nueva institucionalidad que se construiría, no se estarían movilizando en contra de algo o de alguien. Se trataba de una movilización en favor de la vida, en favor de la solidaridad, la convivencia, la tolerancia, que por naturaleza son una resistencia a la violencia. (Efraín Jaramillo, notas de campo, abril de 2012)

El trabajo de campo permitió establecer que el problema se originó cuando se fundó la Asociación de Campesinos e Indígenas del Naya (Asocaidena), organización que se formó poco después de la masacre de abril de 2001, entre personas que también fueron afectadas por el bloque Calima ${ }^{46}$. La organización se integró en 2003, y una de sus primeras acciones fue entablar una acción judicial contra el Estado, invocando, en calidad de desplazados, el derecho a la tierra. Efectivamente, un juez concedió la demanda y obligó a que el desaparecido Instituto Colombiano de la Reforma Agraria (Incora) ofreciera una solución en un término perentorio. La solución fue comprar la finca La Laguna, ubicada a quince minutos de la ciudad de Popayán, capital departamental del Cauca. Después de obtenido el título de propiedad, los dirigentes de Asocaidena tramitaron ante la dirección de Etnias del Ministerio del Interior la solicitud de formación del Cabildo Kitet Kiwe ("tierra floreciente"), que efectivamente fue concedida. En ese contexto, para la dirigencia de la organización y para las familias que se asentaron en un nuevo territorio tras los duros años de vivir en condición de desplazamiento forzado, resultaba más beneficiosa la indemnización económica e individual, alentada, además, por la ong Minga, cuyos abogados se convirtieron en representantes legales de las víctimas.

Otra fue la lectura de los líderes y las familias que decidieron retornar a la región del Alto Naya para avanzar en una solución integral

46 Lectura similar tiene el antropólogo Efraín Jaramillo, quien ha acompañado los procesos organizativos en la región del Naya a través del Colectivo de Trabajo Jenzera (Jaramillo, 2011, p. 213). 
y solidaria que comprometiera los intereses de los tres grupos poblacionales. Para ellos, la indemnización individual, aunque era una forma de reparación, no era una solución que permitiría encarar los problemas que las comunidades aún viven. Para los pobladores que decidieron quedarse en el territorio, una verdadera reparación integral implica priorizar: a) titulación plena de la cuenca del río Naya; b) identificación y restablecimientos de las condiciones que permitan la reconstrucción de las economías familiares; c) restablecimiento de los servicios básicos por las instituciones estatales: educación, salud, vivienda ${ }^{47}$; d) apoyo a la recuperación de la dinámica social interétnica, que permita el fortalecimiento del tejido social.

La situación pone de manifiesto las tensiones, rencillas y fracturas que se registran en las comunidades y las organizaciones, y que desvirtúan el imaginario en torno a grupos de "víctimas" homogéneos y unificados en intereses comunes ${ }^{48}$. En este caso resulta claro que Asocaidena y Kitet Kiwe no solo tienen propósitos distintos, sino que también hacen valer la estratégica cercanía que tienen con la capital departamental para agenciar sus demandas ante instituciones estatales, gubernamentales y entidades de cooperación internacional. El conflicto, de acuerdo con la lectura que hacen los líderes de las comunidades del Alto Naya, se

47 Los relatos sobre las condiciones de educación y salud en la región del Alto Naya son dramáticos, pues se carece de los recursos básicos de infraestructura y personal para atender las necesidades de las comunidades. En el servicio de salud, los pobladores pueden referir casos de personas que, por enfermedad o accidente, han tenido que recorrer más de diez horas por caminos de herradura.

48 A mi modo de ver, la negación social que han tenido las víctimas del conflicto armado en Colombia en el pasado reciente ha permitido aclimatar una serie de imágenes, representaciones y estereotipos en torno a lo que es ser víctima. Esas imágenes, representaciones y estereotipos responden a unos códigos sociales que usualmente no se problematizan. En consecuencia, se tiende a asumir a las víctimas como una comunidad cohesionada en torno a intereses política y socialmente compartidos, desdeñando las fracturas y las fricciones que de manera inevitable aparecen cuando se están agenciando capitales de distinta índole. De igual modo, tampoco se problematizan los testimonios de las víctimas, asumidos como verdades irrefutables que tienen que corresponder a unas representaciones que deben poner a flor de piel la narrativa dolorosa, de alguien que es creíble porque exhibe siempre los traumas que dejó la guerra. 
produce cuando ese agenciamiento se hace a nombre de lo que socialmente ya se reconoce como las víctimas del Naya.

Si ellos quieren llamarse "víctimas del Naya" no hay problema, pero no pueden hacerse pasar por todas las "víctimas del Naya". Ellos deberían aclarar que son tan sólo un grupo que fue afectado por la masacre, que ya tienen un terreno propio, que lo que gestionan lo hacen a nombre de esa comunidad, pero que el grueso de las comunidades víctimas de la masacre simplemente retornó a la región y que aún siguen buscando la titulación del territorio. (María, notas de campo, septiembre de 2013)

La tensión entre los líderes de Asocaidena y Kitet Kiwe con los líderes de las comunidades del Alto Naya tuvo un manejo político prudente y moderado. En el acompañamiento a varios eventos pude constatar que el malestar siempre se mimetizó en posturas públicas que privilegiaban la unidad y la cohesión, pues como lo señalaron varios dirigentes, "la ropa sucia se lava en casa". Pero esta posición cambió a comienzos de 2014, cuando los líderes del Alto Naya enviaron una misiva a varias instituciones del orden nacional y departamental, denunciando el agenciamiento por parte del cabildo Kitet Kiwe de recursos monetarios a favor de las víctimas del Naya, sin que éstas hayan otorgado autorización alguna para ser representados. La carta sostiene:

Desafortunadamente, la corrupción y la falta de escrúpulos de algunas personas ajenas a nuestra comunidad, que lo único que buscan es satisfacer intereses personales, actúan y utilizan nuestro proceso y el nombre de la región del Alto Naya, desviando recursos que nunca nos han llegado a nosotros y nosotras como víctimas reales. Debido a esto, nos vemos en la obligación de aclararle a la opinión pública, a los entes de control [...] a las entidades del Estado $[\ldots]$ y a los organismos internacionales [...] que las víctimas de la región del Alto Naya están representadas únicamente por el señor Hugo Giraldo y Manuel Tenorio. Teniendo en cuenta lo anterior, la comunidad del Naya solicita que se detenga todo lo que se viene adelantando con la propuesta que el cabildo Kitet Kiwe ha presentado en el marco de la reparación individual y colectiva 
[...] en vista de que se han venido realizando indemnizaciones y otros proyectos en nombre de nuestra comunidad sin la debida autorización.

El temor que tienen los líderes y dirigentes de la región del Alto Naya está en las lecturas que pueden efectuar las entidades estatales encargadas de atender a las víctimas del conflicto, pues tendrían la legitimidad para considerar que el Estado colombiano ha venido reparando civilmente a los afectados de la región del Naya. Pero la denuncia también indica las miserias que se tejen en torno a la guerra, expresadas en la cosificación y la mercantilización de lo que rodea a una comunidad que trata de (re)construir sus identidades sobre la base de un autorreconocimiento en su condición de víctimas. Aspectos como el dolor o el testimonio, y el hecho de ser víctima, se convierten en mercancías que se comercializan en distintos escenarios.

Volviendo al caso del Naya, las discusiones que se dieron en los encuentros interétnicos plantearon la importancia de que la (re)construcción del tejido social y organizativo trascendiera el dolor como elemento en torno al cual se cohesionara el agenciamiento. La postura de los participantes fue reconocer el daño social, cultural, político y económico que provocó el bloque Calima en la región, bajo la complacencia de un Estado indolente e indiferente, entendiendo que el reclamo se tenía que proyectar según la dignidad y no según el dolor; como lo escuché decir en varias oportunidades, no se necesita mendigar la asistencia o la ayuda del Estado, se requiere exigir lo que el Estado debe garantizar a cualquiera de sus ciudadanos "porque así lo establece la constitución y las leyes".

Recapitulando, el surgimiento de una organización (Asocaidena) en momentos en que se adelantaban los encuentros interétnicos truncó una iniciativa colectiva que intentó instalar en la agenda de la negociación con las instituciones del Estado la interculturalidad como elemento central, siendo la titulación del territorio la mayor y la más importante aspiración. Las legítimas demandas civiles que apostaron por indemnizaciones monetarias individuales, tras la entrega de un terreno que dará vida al cabildo Kitet Kiwe, frustró un proceso organizativo y social que tuvo en su horizonte una reparación integral y colectiva. 
No obstante, las discusiones y apuestas continuaron en un nuevo escenario: la escuela interétnica.

\section{La Escuela Interétnica: proceso de formación política}

A pesar de la frustración experimentada después de los cuatro encuentros interétnicos, al no lograrse consolidar una agenda común en torno al territorio, los líderes de las comunidades del Alto Naya continuaron trabajando con el apoyo de una ONG comprometida desde un comienzo con el proceso de recuperación y reivindicación: el Colectivo de Trabajo Jenzera $^{49}$. Quizá, la más significativa de las lecciones aprendidas tras ese primer esfuerzo de organización comunal, fue reconocer la importancia de continuar con la formación política de las comunidades. De ahí que los pobladores del Naya comenzaron a formar parte de una apuesta política y social que, bajo la orientación del antropólogo Efraín Jaramillo como cabeza del Colectivo de Trabajo Jenzera, aún busca la cualificación de las comunidades del Pacífico colombiano a través de una Escuela Interétnica.

La escuela comienza a trabajar en 2007 con reuniones de cualificación y capacitación sobre temas que fueron previamente concertados con los líderes de las organizaciones de las regiones del Naya y del Bajo San Juan, departamento del Chocó. La dinámica parte del principio de que los participantes de los procesos deben ser multiplicadores de la experiencia. De acuerdo con el Colectivo de Trabajo Jenzera, los objetivos son:

a. Apoyar y acompañar iniciativas, procesos y estrategias de las comunidades negras e indígenas tendientes a fortalecer

49 Grupo de trabajo con perfil interdisciplinario y con experiencia en el acompañamiento a pueblos indígenas, afrocolombianos y campesinos en varias regiones de Colombia. La conformación del grupo se inicia en 1995, cuando se acompaña al pueblo emberá katío del Alto Sinú, vulnerado por la empresa Urra S.A. El nombre jenzera, que en lengua emberá significa hormiga, fue idea del desaparecido líder Kimy Pernía Domicó. 
la apropiación legal, económica, política y cultural de sus territorios para que no los abandonen o los cedan a otros actores más fuertes con intereses económicos diferentes.

b. Mejorar la calidad de vida de las comunidades por medio del desarrollo de una economía propia.

c. Conservar el patrimonio natural y la oferta ambiental de sus territorios.

d. Contribuir a la paz de la región por medio de un desarrollo intercultural.

La propuesta, entonces, ahonda en cuatro temas que se desarrollan en los módulos de trabajo, estructurados en áreas de interés específicas:

- Primer módulo: historia política, social y económica de Colombia.

- Segundo módulo: procesos organizativos y gestión local.

- Tercer módulo: territorialidad y resolución de conflictos.

- Cuarto módulo: políticas públicas e instrumentos jurídicos.

Además de realizar en 2008 una jornada especial con las comunidades del Naya para elaborar un diagnóstico sobre derechos humanos, la Escuela Interétnica ha sido una plataforma sustancial para encarar las discusiones comunitarias en torno a la titulación del territorio, centradas en alcanzar consensos respecto a la figura legal más conveniente para todas las comunidades que habitan la región ${ }^{50}$. La interculturalidad sigue siendo estratégicamente la marcación social que engloba

50 Las agendas de trabajo de la Escuela Interétnica varían de acuerdo con los intereses de las comunidades. En las poblaciones asentadas en la parte baja del río Naya, resguardo de Joaquincito, que consiguieron la titulación a comienzos de 2013, las discusiones giraron en torno a consolidar lo que en el plano comunitario denominan un plan de vida, entendido como mecanismo-estrategia-herramienta que tienen los pueblos indígenas para trazar sus rutas de "desarrollo" según sus cosmovisiones y sus prácticas étnicas y culturales (Gamboa, 1999). 
la participación de las comunidades, puesto que no se renuncia a que el territorio sea el factor que ayude a cimentar sus identidades como pobladores del Naya. No obstante, el hecho de que las comunidades tengan que escoger entre resguardo, consejo comunitario o reserva campesina permite avizorar una reconfiguración de las marcas de autorreconocimiento, pues, como sostuvo en su momento Elvira, quien desde un comienzo soñó con la figura de resguardo, "una vez escogida la figura legal, tendremos que ponerle la ' $I$ ' de indígenas, la 'A' de afros o la 'C' de campesinos a este proceso". En otras palabras: trascendiendo la imagen de una comunidad cohesionada en torno a un territorio común, los pobladores no desconocen que la eventual figura de titulación imprimirá unas características que, de una u otra forma, moldearán las marcaciones sociales futuras.

\section{La decisión por la figura del resguardo}

Las comunidades de la región del Alto Naya dieron un paso fundamental en 2013, cuando decidieron acoger la figura del resguardo para solicitar al Incoder la titulación de los territorios. Y si bien el ejercicio estuvo caracterizado por la presión ejercida por las Farc-EP, quienes buscaron mediante amenazas y destierros temporales contra los principales líderes del proceso imponer la zona de reserva campesina, la decisión comunal fue defendida con firmeza ${ }^{51}$. Reunidos en el municipio de Santander de Quilichao, los líderes recuerdan que el ejercicio de consulta fue dispendioso y agotador:

51 Lo particular es que los líderes no ofrecen una explicación sobre por qué las Farc-EP respetaron la decisión adoptada por las comunidades. Por otra parte, cabe señalar que las presiones, las amenazas y los desplazamientos han sido una constante para los líderes a lo largo del proceso, en su mayoría perpetrados por las Farc-EP. En ese contexto, cabe recordar el asesinato de Alexander Quintero, presidente de la Asociación de Juntas de Acción Comunal del Alto Naya en mayo de 2010. Aunque la responsabilidad no ha sido establecida oficialmente, las comunidades sellaron el asunto responsabilizando del crimen a los paramilitares. 
Fueron jornadas extenuantes, algunas de más de seis, siete u ocho horas de caminata, todo dependiendo de la vereda. Reunir a la gente es más sencillo, pero eso cuesta... la sola comida es un gasto muy grande, así que las reuniones colectivas las dejamos para los momentos en que prácticamente teníamos que ratificar decisiones. De resto fue trochar por el territorio, convenciendo a las comunidades de la importancia del proceso, que comprendieran que nuestra supervivencia como pueblos está en su titulación. (María, notas de campo, septiembre de 2013)

Trascendiendo lo dispendioso que resulta un ejercicio de consulta en el que los recursos económicos son limitados, lo interesante del proceso es comprender cómo se llega a unos acuerdos que definen en buena parte el futuro de las comunidades. A mi modo de ver, en el trabajo adelantado por un pequeño grupo de líderes — que actuaron en representación de todos los grupos poblacionales- subyace una estrategia comunicativa que apeló a la memoria para sensibilizar a los pobladores sobre la importancia de alcanzar acuerdos para solicitar la titulación de los territorios, y orientando las discusiones de tal forma que el resultado final fuera la escogencia del resguardo como la opción más indicada. En esta forma, como producto del trabajo adelantado en el marco de los encuentros y de la Escuela Interétnica se asumió que el resguardo era la figura más conveniente para encarar la titulación. Esta decisión implicó que los líderes del proceso desarrollaran un ejercicio de diálogo y consulta en el que su objetivo final consistía en convencer a los otros frente a una realidad construida con anterioridad.

En ese contexto, las personas que estuvieron al frente del proceso asumieron una suerte de actuaciones para representar un interés muy concreto, legitimado por la condición que los líderes tienen como autoridades reconocidas por todas las comunidades. Ello no significa que las actuaciones y las representaciones sean producto de un acto artificioso o prefabricado (Goffman, 2009, p. 86), pues expresan un rol sincero que pone de manifiesto el convencimiento que tuvieron los líderes respecto a lo que ellos consideraron que era lo más conveniente para la región. En el marco de esas actuaciones, la memoria adquiere una 
dimensión importante en la medida en que se usa como herramienta que contribuye a reforzar unas argumentaciones que asumen la posición de un nosotros en relación con unos otros, concebidos, además, como posibles amenazas (Butler, 1995).

El ejercicio de memoria fijó su atención en un pasado reciente que incluyó ciertos eventos disruptivos —ejercidos tanto por paramilitares del bloque Calima como por los dos grupos insurgentes que históricamente han tenido injerencia en la región-, asumiéndolos como acontecimientos del pasado que dejan grandes lecciones para encarar el presente y proyectar el porvenir. Algunos de esos eventos ocurrieron en la región del Alto Naya, otros sucedieron en territorios indígenas del departamento del Cauca que las autoridades y las organizaciones convirtieron en emblemas de la lucha por el territorio ${ }^{52}$.

Lo principal de esos ejercicios de memoria está, por un lado, en la socialización colectiva cuyo propósito es “tejer”, en palabra de los líderes, unos vínculos y reforzar unas identificaciones que se fracturaron cuando las comunidades tuvieron que afrontar el desarraigo social que provocó el desplazamiento forzado de los territorios; por otro lado, asumir la memoria como ejercicio de aprendizaje en el que el "dolor", como un elemento siempre presente en las narraciones, se redimensiona y se trasciende, para que los eventos del pasado no encapsulen

52 En la historia reciente, quizá el evento más importante esté representando por la masacre en la hacienda El Nilo, ocurrida el 16 de diciembre de 1991, cuando 20 indígenas nasa fueron asesinados mientras intentaban recuperar parte del predio, ubicado en el municipio de Caloto. Producto de la masacre, el gobierno de César Gaviria Trujillo suscribió un acuerdo en el que el Estado colombiano se comprometía a titular 16663 hectáreas a las comunidades aborígenes del norte del Cauca. En el año 1992, las comunidades presentaron ante la Comisión Interamericana de Derechos Humanos (CIDH) una demanda contra el Estado colombiano por la ejecución sumaria de los indígenas, al comprobarse en las investigaciones judiciales la participación de la fuerza pública. En el año 1995, el Estado colombiano aceptó una solución amistosa, acogiendo una serie de recomendaciones formuladas por la CIDH, entre ellas el derecho al territorio y a la autodeterminación. No obstante, el 28 de septiembre de 1999, la CIDH aprobó el informe 114/99 en el que responsabiliza al Estado colombiano de la masacre de los 20 aborígenes y reitera la obligación de reparar socialmente a las víctimas. 
el presente sino que se conviertan en los referentes que dinamicen un trabajo de agenciamiento que debe concluir con la titulación de los territorios. En ese contexto, la escogencia del resguardo como figura de una eventual titulación es un logro preponderante para la consolidación y la proyección de las comunidades que renace en medio de su lucha histórica por la recuperación del territorio, en la que también se reconoce la recuperación y el afianzamiento de una tradición de lo que Jan Asmmann y John Czaplicka (1995) y Jan Asmmann (2006) denominan memoria cultural. Esa lucha por la recuperación del territorio es enmarcada por los líderes del Naya en un horizonte más amplio que cobija a los pueblos indígenas del Cauca, quienes convirtieron la recuperación de la tierra en su principal consigna política y social.

De acuerdo con Jan Assmann (2006) la memoria tiene una base social pero también una base cultural que franquea la oposición que Halbwachs estableció entre memoria y tradición. Para Assmann (2006), la tradición también forma parte de la memoria porque tiene la función de mantener vivos unos recuerdos que no tienen un sustento en la vida cotidiana (p. 28). Para comprender mejor el argumento, hay que comenzar por distinguir entre lo que los esposos Assmann definen como "memoria comunicativa" y "memoria cultural". La primera forma parte de lo que también sería una "memoria vinculante" (p. 21) que se configura en la interacción y en las relaciones diarias a través de prácticas comunicativas que no tienen papel distinto al de establecer relaciones sociales. En ese sentido, la "memoria comunicativa" tiene su resonancia en la memoria individual a la que alude Halbwachs, dado que se registra en el ámbito de una cotidianeidad que se inserta en un marco social en el cual adquiere sentido. Su tarea, por lo mismo, es construir-transmitir una identidad colectiva en una temporalidad en todo caso restringida, pues no abarcaría un periodo mayor de cien años que la termine anclando a un horizonte de larga duración.

Frente a esta limitación y discutiendo con Halbwachs, tanto Jan como Aleida Assmann (1999) introducen la categoría de "memoria cultural" que, formada a la distancia de cinco o más generaciones, incorpora acontecimientos, lugares o personas que permanecen en el relato del grupo, usualmente vinculados a los mitos fundacionales, así como a las representaciones sociales de un pasado ya no tan reciente. 
Los Assmann piensan en textos, ritos, objetos o imágenes que, como artefactos culturales preservados, están a disposición del grupo y funcionan como registros y catalizadores que permiten recomponer la memoria. La "memoria cultural", entonces, es el resultado de relacionar tres elementos: un pasado (re)significado, la cultura y el grupo social. En esta forma, adquiere seis características:

a. La preservación de la identidad, en la medida en que resguarda un acervo de conocimientos que otorgan unidad.

b. La capacidad de (re)construcción y (re)significación en un ejercicio que implica el reconocimiento y la potencialidad de los archivos (textos, imágenes, normas de conducta, etc.) que permiten trazar un horizonte ${ }^{53}$.

c. La formación, entendida como un ejercicio de comunicación que se objetiva para transmitir la herencia cultural a través de la escritura, imágenes pictóricas y rituales.

d. La organización, reflejada en prácticas culturales especializadas (ritos, ceremonias, canciones, etc.), mediante las cuales se "cultiva" el acervo cultural.

e. La obligación, definida por Assmann como el sistema de valores que se va configurando a través de la prácticas culturales y que varían de acuerdo con la función social respecto a la producción, representación o reproducción.

La última característica está en la reflexividad como un ejercicio permanente que permite que el grupo pueda (re)leer y (re)interpretar sus

53 En trabajos posteriores, Aleida Assmann (1999) continuó desarrollando este argumento, distinguiendo entre la "memoria acumulada" y la "memoria funcional". La "memoria acumulada" atañe a la manera como se recoge, cataloga y archiva un material, sin que este tenga en principio un uso; la "memoria funcional”, por su parte, se configura cuando el material es cargado de un valor y de un sentido que se reproduce en los escenarios sociales: familia, escuela, iglesia, etc. 
prácticas sociales y culturales, entre otros aspectos, para (re)significarlas. Aunque Assmann no lo menciona de manera explícita, esa (re)significación sería en función de las circunstancias sociales (re)conocidas en un presente. El concepto de memoria cultural desarrollado por los esposos Assmann abarca un cuerpo de textos, imágenes, rituales cuyo "cultivo" permite al grupo reproducir y transmitir un acervo común que otorga conciencia, unidad e identidad (Assmann y Czaplicka, 1995, pp. 130-131).

Ahora bien, Assmann no elude la discusión que concibe la tradición como parte de una herencia biológico-genética que luego es conscientemente transmitida en prácticas culturales. Dialogando con el ensayo de Jacques Derrida en torno a lo que este define como "mal de archivo" (Assmann y Czaplicka, 1995), pero también con los planteos de Richard Bernstein respecto a la definición de tradición, Assmann considera que la memoria cultural no es el resultado de una transmisión genética e inconsciente, pues desde una perspectiva cultural, no hay comprensión sin memoria y no hay existencia sin tradición (Assmann, 2006).

Volviendo a la región del Alto Naya, hay un ejercicio de memoria vinculante y aleccionadora que, parafraseando a Assmann, instrumentaliza los recuerdos en función de lograr esa cohesión social para la toma de decisiones. Pero esos ejercicios también envuelven una dimensión más profunda ligada a una memoria cultural que emerge con toda su fuerza cuando la escogencia del resguardo y la consolidación de los cabildos enmarcan los sentidos del pasado a la resistencia que histórica y sistemáticamente han dado las comunidades aborígenes del departamento del Cauca por el territorio (Jaramillo, 2011; Tattay, 2013). La recuperación del nasa yuwe como lengua del pueblo nasa, la presencia del tewala como médico tradicional que guía las prácticas cotidianas de las comunidades o la organización de la guardia indígena para proteger los territorios de los actores armados en el ejercicio de una autonomía territorial son acciones que en la actualidad se discuten en el marco de esas estrategias de resistencia social, política y cultural por el territorio. Estas se acompañan de un trabajo de recopilación y estudio de documentación, especialmente legal, por algunos líderes que comprenden que en esos "papeles", como los llama Elvira, también reposan los elementos de una reclamación legítima. Cabe recordar que 
esa ha sido una estrategia eficaz implementada por los pueblos indígenas del Cauca desde los años setenta, cuando comienzan un ejercicio de relectura del marco normativo, comenzando por la Ley 89 (1890), acompañado de un proceso de formación y cualificación que incluyó el estudio de la legislación indígena. Ese ejercicio responde a otra estrategia que ha caracterizado la dinámica política y organizativa de los pueblos del Cauca: el trabajo desde adentro.

Como lo señala Pablo Tattay (2013), ese trabajo implica iniciar las capacitaciones reconociendo la situación de la gente a través de reuniones y asambleas en los que se identifican los problemas, también en un abordaje que trabaja en tres niveles de formación:

a. Discusiones en cada comunidad de los problemas locales, congregando resguardos y cabildos, con una amplia participación de todos los pobladores.

b. Discusiones zonales en la que se ahonda en las problemáticas locales y regionales, con la participación de las personas más activas de las comunidades.

c. Discusiones regionales para abordar problemas y estrategias, en la que participan los principales líderes de las comunidades y las organizaciones.

La idea central de ese proceso de capacitación es la conciencia respecto a que las reivindicaciones se construyen, “[d]e ahí que, en la estrategia de capacitaciones, se vuelvan prioritarios temas como el análisis de la correlación de fuerzas para ver qué luchas se pueden dar con buenas probabilidades de éxito" (Tattay, 2013, p. 68).

Y por esa valoración en la correlación de fuerzas, las comunidades del Naya, al escoger el resguardo como figura para la titulación del territorio, también deciden acoplarse a la lógica administrativa que implica un territorio que cobija dos departamentos. En consecuencia, la solicitud al Incoder implica la titulación de dos resguardos: el primero ubicado espacialmente en el departamento del Cauca y que aglutinaría los cabildos Comunidad Sinaí Nasawala y Comunidad El Playón 
Nasawala; el segundo, en el departamento del Valle, con los cabildos Alto Naya Paez de La Playa y Aguas Limpias de Pico de Loro.

\section{Retos y amenazas}

Adoptada la decisión en torno a la figura del resguardo, comienza el arduo trabajo para que el Incoder inicie el trámite administrativo de titular los territorios. Ese reto se hace en medio de viejas y nuevas amenazas que los pobladores del Naya deben encarar en la apuesta por tener en el futuro un territorio en el que puedan ejercer una verdadera autonomía. En las conversaciones sostenidas con los líderes y con algunos pobladores del Alto Naya, se identifican algunas problemáticas y amenazas muy puntuales, relacionadas con agendas económicas y el uso de los suelos, así como del subsuelo ${ }^{54}$ : por una parte, la constante disputa militar para controlar los cultivos de coca, así como la producción y tráfico de estupefacientes; por otra, una agenda productiva que proyecta sobre los territorios el desarrollo de iniciativas mineras, energéticas y agroindustriales, estas últimas relacionadas con los cultivos de caña de azúcar y pino; finalmente, la alta concentración en la propiedad de la tierra, pues para el año 2000 tan solo un $5 \%$ de propietarios concentraba el $61 \%$ de los predios, lo cual resulta en un coeficiente Gini - que mide los niveles de desigualdad en la distribución de la propiedad de la tierra-calculado para el año 2002 entre 0.8 y 0.9 , acotando que cuanto más cerca a uno, la concentración es mayor (Igac, 2012, p. 75).

54 En la actualidad, se adelantan en la Corte Constitucional y el Consejo de Estado discusiones sobre la injerencia que las comunidades rurales pueden tener en relación con la ejecución de proyectos que implican la extracción de recursos naturales no renovables. En palabras más sencillas, la explotación del subsuelo en zonas rurales, dado que varias comunidades han acudido a mecanismos de participación establecidos por la constitución de 1991 — como la consulta popular- para pronunciarse sobre proyectos mineros y energéticos. La discusión está sobre los alcances que tendría el artículo 37 del Código de Minas (Ley 685 de 2001) y el Decreto 934 (2013), según los cuales la explotación del subsuelo en ese tipo de proyectos es una decisión que compete exclusivamente al ejecutivo, representado por el Presidente de la República. 
Estos tres problemas no son desconocidos por entidades como el Incoder o la Unidad de Restitución de Tierras, instancia creada por la Ley 1448 (2011) o Ley de Víctimas para adelantar los procesos de las personas o las comunidades que en el conflicto armado interno fueron desterradas o despojadas de sus tierras y sus territorios. La mirada de estas instituciones pone el acento en un cuarto problema, generalizado para todo el departamento del Cauca: los conflictos interculturales entre campesinos, indígenas y comunidades negras por la disputa de los territorios, producto del abandono del Estado.

Grosso modo, el argumento es el siguiente: el departamento del Cauca tiene alrededor de tres millones de hectáreas de las cuales $612 \mathrm{mil}$ están tituladas a comunidades indígenas a través de 47 títulos coloniales y reconocidos por Simón Bolívar en 1820, así como 53 títulos otorgados en los últimos años mediante resoluciones otorgadas por el Incoder; 547 mil hectáreas están tituladas a 17 consejos comunitarios de comunidades negras; y el Incoder acepta que no tiene información respecto a los predios titulados o terrenos baldíos ocupados por campesinos. Según la versión oficial asumida por las instituciones, las comunidades indígenas reclaman tierra sobre la base del despojo sufrido desde tiempos de la Colonia, legitimado en el siglo Xvi cuando se incorpora el sistema de haciendas que reduce los territorios a resguardos. Por su parte, las comunidades negras también reclaman tierras como pobladores asentados y descendientes de los esclavos del siglo XVI; y los campesinos no se quedan atrás, pues también reclaman la titulación de los predios que comenzaron a colonizar tras la violencia partidista de los años cincuenta. Sobre ese panorama, el Incoder y el Centro de Estudios Interculturales de la Pontificia Universidad Javeriana de Cali han identificado alrededor de 15 conflictos entre las comunidades indígenas, negras y campesinas por la definición, delimitación y utilización de predios, a los que se suman alrededor de 25 conflictos más entre alguno de los grupos con un actor que representa un interés económico: industria de caña, industria maderera, parques industriales, empresas avícolas, ladrilleras, transnacionales mineras y las instituciones del Estado que promueven proyectos de distinta índole, desde la construcción de carreteras, pasando por la proyección de hidroeléctricas, hasta la construcción de puertos en la costa Pacífica (Incoder, 2013, p. 63). 
Replicando un tanto la experiencia del Alto Naya, la estrategia implementada por el Incoder en 2013 para encarar estas situaciones ha sido el desarrollo de mesas interétnicas e interculturales como escenarios de diálogo y concertación para resolver los conflictos registrados en el departamento.

Sin desconocer que efectivamente en el Cauca se han registrado en los últimos años conflictos entre campesinos, indígenas y negros por la definición, delimitación y posesión de la tierra ${ }^{55}$, resulta claro que la principal dificultad que enfrentan los grupos y las comunidades rurales del departamento del Cauca se relaciona con las agendas económicas de actividades tanto legales como ilegales, cuyos actores se rehúsan participar en cualquier escenario en que se cuestionen sus intereses y procederes:

Que las comunidades nos pongamos de acuerdo no es un asunto fácil, porque cada sector antepone sus intereses, pero es posible

55 Cuando se revisan los casos, se observa que los conflictos han sido propiciados de manera directa o indirecta por las instituciones del Estado. Para ejemplificar el argumento, revisamos cuatro casos documentados por el mismo Incoder (2013): 1) la disputa por el predio El Mediecito o La Selva en zona rural de Popayán, el cual se enfrenta a indígenas del Cabildo de Quintana con 13 familias campesinas; el territorio fue titulado por el Incoder en 2009, pero los indígenas argumentan que ocupan el predio desde 1999 porque forma parte de la solicitud de ampliación del resguardo; 2) un caso similar es el predio El Naranjo, municipio de Cajibío, que fue titulado por el Incoder a 11 familias campesinas desplazadas; el terreno, no obstante, fue tomado por indígenas nasa del Cabildo de Jebalá porque consideran que el predio también forma parte de su reclamación de ampliación del resguardo; 3) en el municipio de Santander de Quilichao, el conflicto enfrenta a indígenas nasa del Cabildo de Toribío y comunidades afro de los consejos comunitarios de Mazamorreros, Brisas del Río Cauca y Cerro Tetas, por los predios San Rafael y Corcovado que fueron titulados a favor de los indígenas por el Ministerio del Interior en 2007 en el cumplimiento del acuerdo del Nilo, y 4) en el municipio de Silvia el conflicto es entre los cabildos indígenas de Ambaló, que pertenece al Consejo Regional Indígena del Cauca (Cric), y Guambía, que pertenece a las Autoridades Indígenas de Colombia (Aico); el problema es por la promesa del Incoder de comprar la finca Puerta de Hierro para entregarla a los indígenas, pero ambos cabildos consideran que el predio les pertenece. Según el Incoder, en la actualidad existen once conflictos más. 
porque, en últimas, todos queremos lo mismo: tener territorio para llevar nuestras vidas. Incluso, muchos problemas han sido por culpa de los gobiernos cuando toman decisiones equivocadas, pero que tengamos un espacio para hablar y llegar a acuerdos es un asunto posible y hasta necesario, porque no importa que seamos negros, indios o campesino, todos tenemos problemas comunes y desde ahí nos reconocemos y aceptamos. Otra cosa es cuando en los territorios la minería o el cultivo de pino o el cultivo de coca es lo que provoca nuestra salida. Sería uno muy tonto pensar que algún comandante o empresario va a sentar con nosotros a negociar... eso es ser iluso. (Rosa Ipía, notas de campo, septiembre de 2013)

Según estas apreciaciones de Rosa Ipía, para los líderes del Alto Naya, considerar que las diferencias entre las comunidades y los grupos es un "grave" problema puede resultar una valoración un tanto distorsionada, sobre todo cuando las mesas interétnicas e interculturales demuestran ser una estrategia eficaz para desactivar eventuales conflictos. Pero es eficaz en cuanto que media la voluntad de una institución oficial que ofrece las condiciones para propiciar el diálogo y los acuerdos. Para los líderes, esa voluntad debería imperar al otorgar la titulación del territorio, pues ese acto es el reconocimiento de un derecho a partir del cual comienzan a consolidar una autonomía que envuelve identidad, gobierno propio y territorialidad, a través de un plan de vida que permite afianzar los cabildos e incorporar la guardia indígena para la defensa del territorio. 
Campamento en el camino real del Naya



Nosotros trabajábamos con listas que nos daba la inteligencia de fuerza pública, Policía y Ejército. Irresponsablemente actuábamos sin verificar la información, con el solo becho de que la fuerza pública nos suministrara esa información, nosotros procediamos y dábamos muertes a esas personas... Éver Veloza García, alias $H H$ 